\title{
LAKES OF THE HURON BASIN: THEIR RECORD OF RUNOFF FROM THE LAURENTIDE ICE SHEETII
}

\author{
C.F. MICHAEL LEWIS, * THEODORE C. MOORE, JR, † DAVID K. REA, DAVID L. DETTMAN, \\ ALISON M. SMITH§ and LARRY A. MAYER\| \\ *Geological Survey of Canada, Box 1006, Dartmouth, N.S., Canada B2Y 4A2 \\ $\dagger$ Center for Great Lakes and Aquatic Sciences, University of Michigan, Ann Arbor, MI 48109, U.S.A. \\ $\ddagger$ Department of Geological Sciences, University of Michigan, Ann Arbor, MI 48109, U.S.A. \\ $\S$ Department of Geology, Kent State University, Kent, OH 44242, U.S.A. \\ IIDepartment of Geomatics and Survey Engineering, University of New Brunswick, Fredericton, N.B., \\ Canada E3B 5A3
}

\begin{abstract}
The $189,000 \mathrm{~km}^{2}$ Huron basin is central in the catchment area of the present Laurentian Great Lakes that now drain via the St. Lawrence River to the North Atlantic Ocean. During deglaciation from $21-7.5 \mathrm{ka} \mathrm{BP}$, and owing to the interactions of ice margin positions, crustal rebound and regional topography, this basin was much more widely connected hydrologically, draining by various routes to the Gulf of Mexico and Atlantic Ocean, and receiving overflows from lakes impounded north and west of the Great Lakes-Hudson Bay drainage divide.

Early ice-marginal lakes formed by impoundment between the Laurentide Ice Sheet and the southern margin of the basin during recessions to interstadial positions at 15.5 and $13.2 \mathrm{ka} \mathrm{BP}$. In each of these recessions, lake drainage was initially southward to the Mississippi River and Gulf of Mexico. In the first recession, drainage subsequently switched eastward along the ice margin to the North Atlantic Ocean. In the second recession, drainage continued southward through the Michigan basin, and later, eastward via the Ontario basin and Mohawk River valley to the North Atlantic Ocean. During the final retreat of ice in the Huron basin from 13 to $10 \mathrm{ka} \mathrm{BP}$, proglacial lake drainage switched twice from the Michigan basin and the Mississippi River system to the North Atlantic via the Ontario basin and Mohawk River valley, finally diverting to the Champlain Sea in the St. Lawrence River valley at about $11.6 \mathrm{ka}$ BP.

New seismo- and litho-stratigraphic information with ostracode data from the offshore lacustrine sediments were integrated with the traditional data of shorelines, uplift histories of outlets, and radiocarbon-dated shallow-water evidence of transgressions and regressions to reconstruct the water level history and paleolimnological record for the northern Huron basin for the 11-7 ka BP period. Negative excursions in the $\delta^{18} \mathrm{O}$ isotopic composition of ostracodes and bivalves in southern Lake Michigan, southwestern Lake Huron and eastern Lake Erie indicate an influx of water from ice-marginal Lake Agassiz in central North America about 11 ka BP. A major decline in water levels of the Huron basin after 10.5 ka BP followed the high-level Main Lake Algonquin phase as ice receded and drainage was established through the North Bay area to Ottawa River valley. During the subsequent Mattawa-Stanley phase, the lake level history was dominated by fluctuations of tens of meters. Highstands of the earliest oscillations, whose origin is not clear, might be related to some of the well known Post Algonquin shorelines. After $9.6 \mathrm{ka} \mathrm{BP}$, it is suggested that large inflows from Lake Agassiz and hydraulic damming in downstream outlets were the likely cause of the Lake Mattawa highstands. A lowstand at 9.3-9.1 ka BP occurred when these inflows were diverted, or impeded by an ice advance in the Nipigon basin area, while undiluted meltwater continued to enter the Huron basin. Assemblages and isotopic composition of the ostracode fauna indicate very dilute meltwater during the lowstands as late as $7.5 \mathrm{ka} \mathrm{BP}$, and precipitation runoff with comparatively higher dissolved solids during the highstands. We speculate that the water composition of the Lake Mattawa highstands was dominated by the Agassiz inflows; by that time, much of Lake Agassiz was remote from ice-marginal environments, and the inflows were drawn from surface water of the southern sector of the lake, which was largely supplied by runoff and dissolved solids from the exposed land area of western Canada. Major inflows apparently ended about $8 \mathrm{ka} \mathrm{BP}$, but northern proglacial lakes apparently continued as meltwater persisted in the Huron basin until about $7.5 \mathrm{ka}$ BP. The cessation of major inflows initiated the final lowstand in the Huron basin and the present hydrological regime of local runoff.
\end{abstract}

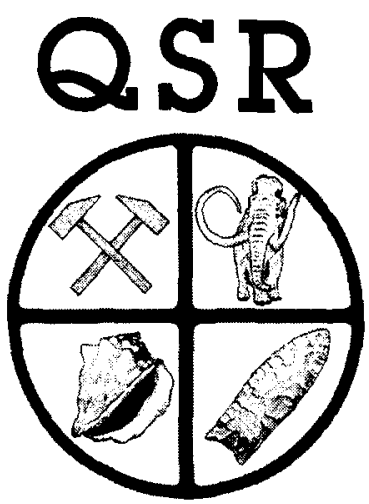

\section{INTRODUCTION}

The Lake Huron basin (Huron basin), which includes Georgian Bay and the Nipissing lowland to the northeast, extends $500 \mathrm{~km}$ north-south and $450 \mathrm{~km}$ east-west with

qTGeological Survey of Canada Contribution 55794. overall relief greater than $400 \mathrm{~m}$. It is a major component of the Laurentian Great Lakes catchment area draining via the St. Lawrence River to the Atlantic Ocean (Figs 1 and 2 ). The Huron basin presently receives inflow from Lakes Michigan and Superior and drains to Lake Erie. Formerly, it occupied a strategic position during retreat of the southern margin of the Laurentide Ice Sheet. It was 


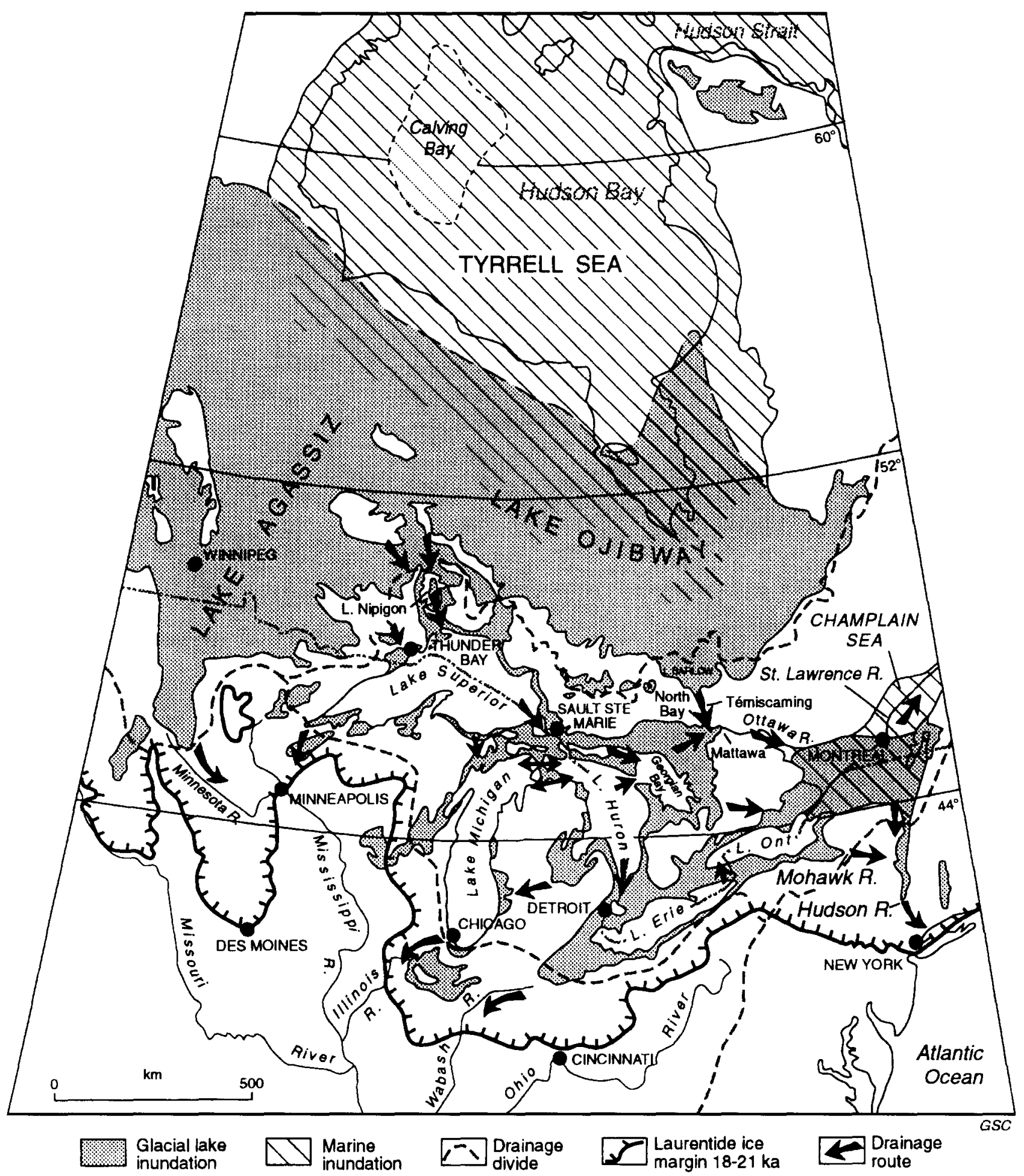

FIG. 1. Map showing location of the Lake Huron basin in relation to drainage divides in central North America, the 18-21 ka BP glacial maximum, and glacial lakes Agassiz, Ojibway and Barlow. The cumulative areas of inundation by glacial lake and marine waters are shown together with routes (arrows) of principal lake outlets (adapted from Teller, 1987; Barnett, 1992).

linked with lateglacial drainage inflow routes from westcentral North America via the Lake Superior basin (Superior basin) to its northwest, and with those from northern Ontario and Quebec via the Ottawa Valley to its northeast; both of these areas now drain to Hudson Bay. In addition, it discharged southeastward for a time during ice retreat directly to the Lake Ontario basin (Ontario basin) and the Champlain Sea in the upper St. Lawrence Valley. At other times, overflow from the Huron basin went via the Lake Erie basin (Erie basin) or the Lake Michigan basin (Michigan basin) over the drainage divide south of the Great Lakes to the Gulf of Mexico.

Glacial lake phases in the Huron basin have long attracted the attention of glacial and Quaternary geolo- 


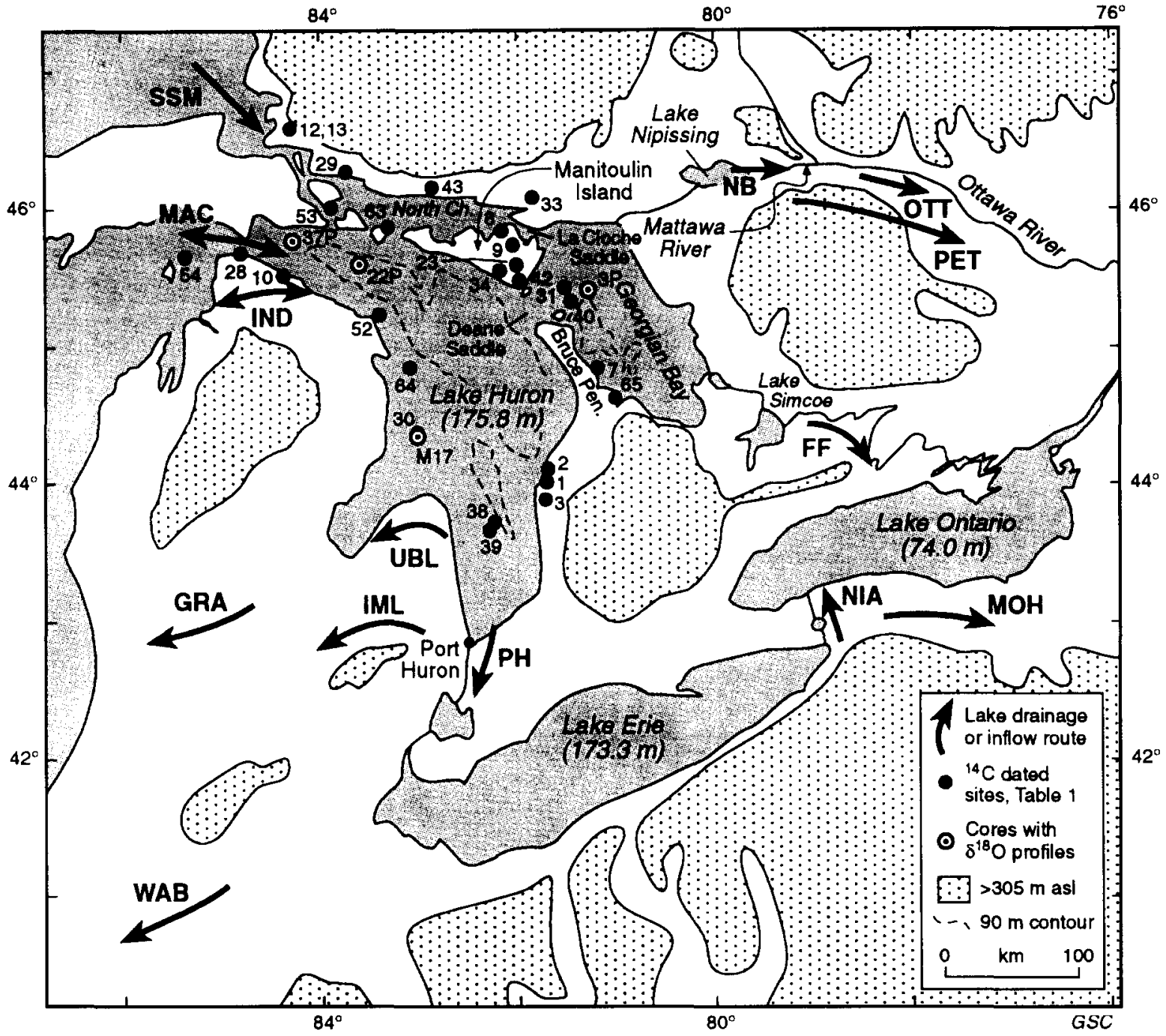

FIG. 2. Map showing regional relief above the $305 \mathrm{~m}$ contour, the $90 \mathrm{~m}$ isobath in Lake Huron and Georgian Bay, and flow direction through lake outlets of the Huron basin including Georgian Bay and the Nipissing-Mattawa lowland. Numerals refer to positions of radiocarbon-dated sites listed in Table 1 , and cores with $\delta^{18} \mathrm{O}$ profiles. The arrows represent drainage routes and lake outlets as follows: FF - Fenelon Falls; GRA - Grand River valley; IML — Imlay channel; IND Indian River lowland; MAC - Straits of Mackinac; MOH - Mohawk River valley; NIA - Niagara River; NB - North Bay outlet; OTT — Ottawa River valley; PET - Petawawa; PH — Port Huron; SSM - Sault Ste. Marie; UBL — Ubly; WAB - Wabash River valley.

gists since Spencer (1891) first described shorelines there of former glacial lakes. Syntheses of these or later-discovered lake phases, sediments, or their glacial margins have been prepared at various times over the past 80 years for all or part of the Laurentide ice retreat history, for example; by Leverett and Taylor (1915), Hough (1958, 1963, 1966, 1968), Chapman and Putnam (1966, 1984), Dreimanis (1969), Lewis (1969), Prest (1970), Sly and Lewis (1972), Sly and Thomas (1974), Farrand and Eschman (1974), Karrow et al. (1975), Evenson and Dreimanis (1976), Fullerton (1980), Eschman and Karrow (1985), Dyke and Prest (1987), Larson (1987), Karrow (1989) and Barnett (1992).

Paleohydrological studies of the basin are much scarcer. Farrand and Drexler (1985) pointed to Lake Agassiz catastrophic flooding as a potential cause of surges and as the likely erosive force which destroyed a drift dam in the outlet of Superior basin to Huron basin.
Teller $(1985,1987,1990)$ considered the possible sedimentological effects of catastrophic discharge from glacial Lake Agassiz into Superior, Huron, and downstream basins; he later calculated meltwater runoff and variations in cumulative lake surface area for basins, including the Huron basin, along the southern Laurentide ice margin. Lewis and Anderson $(1989,1992)$ and Anderson and Lewis (1992) correlated changes in lake level, lake area and climate with inflows from upstream glacial lakes Agassiz and Barlow-Ojibway. Two periods of inflow from Lake Agassiz have also been documented by Colman et al. $(1990,1994 a, b)$ into the southern Michigan basin.

In this paper we first outline the development of proglacial lakes impounded by the retreating Laurentide Ice Sheet in the southern Huron basin. Then we review and synthesize the paleoenvironment of the northern Huron basin, which reflects major inflows from other 
watersheds, by integrating both onshore and offshore evidence. Finally, we explore the implications of these findings for regional aspects of runoff from the southern margin of the Laurentide Ice Sheet.

\section{ICE RECESSION AND LAKE FORMATION}

At the last glacial maximum (Nissouri Stade), about 18-21 ka BP, the Laurentide ice margin lay south of the Huron and Erie basins beyond the Great Lakes drainage divide (Figs 1 and 3a). Meltwater would have flowed directly via tributaries to the Mississippi River and Gulf of Mexico. Lakes formed only when ice retreated far enough so that meltwater and runoff were impounded between the ice margin on the north and the Great Lakes-Gulf of Mexico drainage divide to the south. These basins were deeper toward the north than the present topography would suggest, owing to increased crustal depression to the north under the weight of the Laurentide ice load. For example, the Sault Ste. Marie area (northwestern Huron basin) was at least $120 \mathrm{~m}$ lower at the time of the Main Lake Algonquin phase about 10.7 ka BP (Leverett and Taylor, 1915; Hough, 1958; Walcott, 1972; Larsen, 1987; Lewis and Anderson, 1989).

The early lakes first resided in the Erie basin and later expanded northward into the Huron basin when ice receded north of Port Huron. The retreat of ice from its maximum southern position was oscillatory with major recessions reaching the Huron basin in the Erie Interstade (about $15.5 \mathrm{ka} \mathrm{BP}$ ), the Mackinaw Interstade (about 13.2 ka BP) and the Two Creeks Interstade (about $11.9 \mathrm{ka}$
BP). The interstadials mark periods of glaciological reorganization as most are followed by significant readvances; the activity signifies an adjustment of the ice profile and possibly the presence or release of subglacial meltwater (Kamb et al., 1985; Hughes, 1987; Barnett, 1992).

\section{Ice Retreat to the Erie Interstadial Position (15.5 ka BP)}

Retreat during the Nissouri Stade and Erie Interstade brought the ice margin north of Port Huron, exposing the southern Huron basin and Saginaw Bay (Fig. 3b). Drainage was probably southward into the Erie basin and then eastward along the ice margin in the Ontario basin to the Mohawk Valley outlet (MOH, Fig. 2) and the North Atlantic Ocean (Dreimanis 1969; Morner and Dreimanis, 1973; Fullerton, 1980; Barnett, 1992).

\section{Ice Retreat to the Mackinaw Interstadial Position (13.2 $\mathrm{ka} \mathrm{BP}$ )}

Ice advanced to a new position south of the drainage divide at about $14.8 \mathrm{ka}$ BP following the Erie Interstade (Fig. 4a). Fluctuating retreat during this Port Bruce Stade produced the Maumee (Figs 4b, c) and Arkona (Fig. 4d) series of glacial lakes against the southern divide, generally expanding in area, falling in elevation, and switching drainage routes as new outlets were uncovered (Eschman and Karrow, 1985; Calkin and Feenstra, 1985; Barnett, 1992). At its maximum retreat position the ice margin exposed southern Georgian Bay and most of the southern
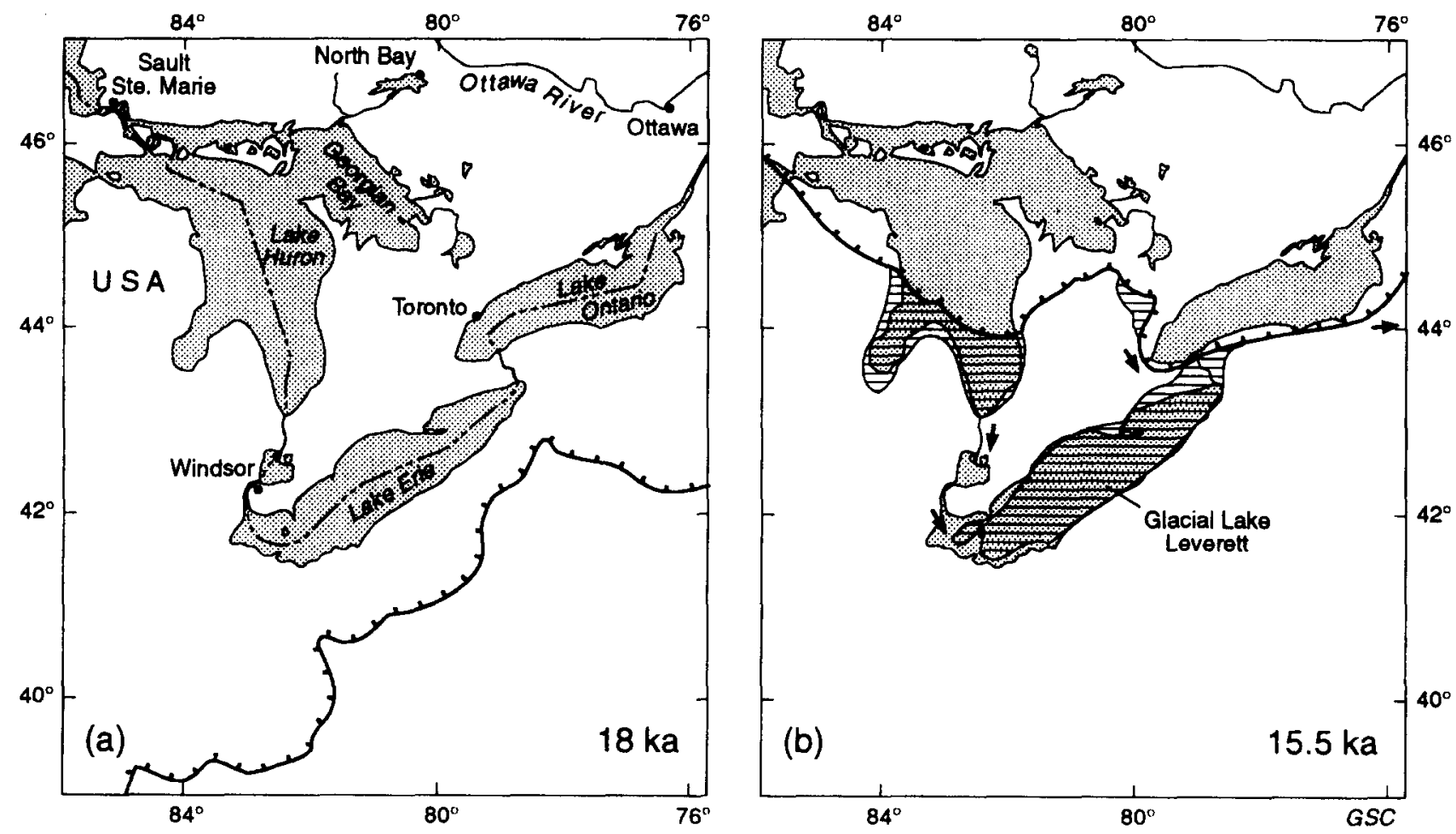

FIG. 3. Maps of ice margins and proglacial lake shorelines during ice retreat to the Erie Interstade position (after Dreimanis, 1969; Morner and Dreimanis, 1973; Barnett, 1992): (a) ice margin at the $18 \mathrm{ka}$ BP (Nissouri Stade) maximum position, no lakes are impounded as the margin lies south of the Great Lakes-Gulf of Mexico drainage divide; (b) maximum extent of lakes inferred for the Erie Interstade ice position. 

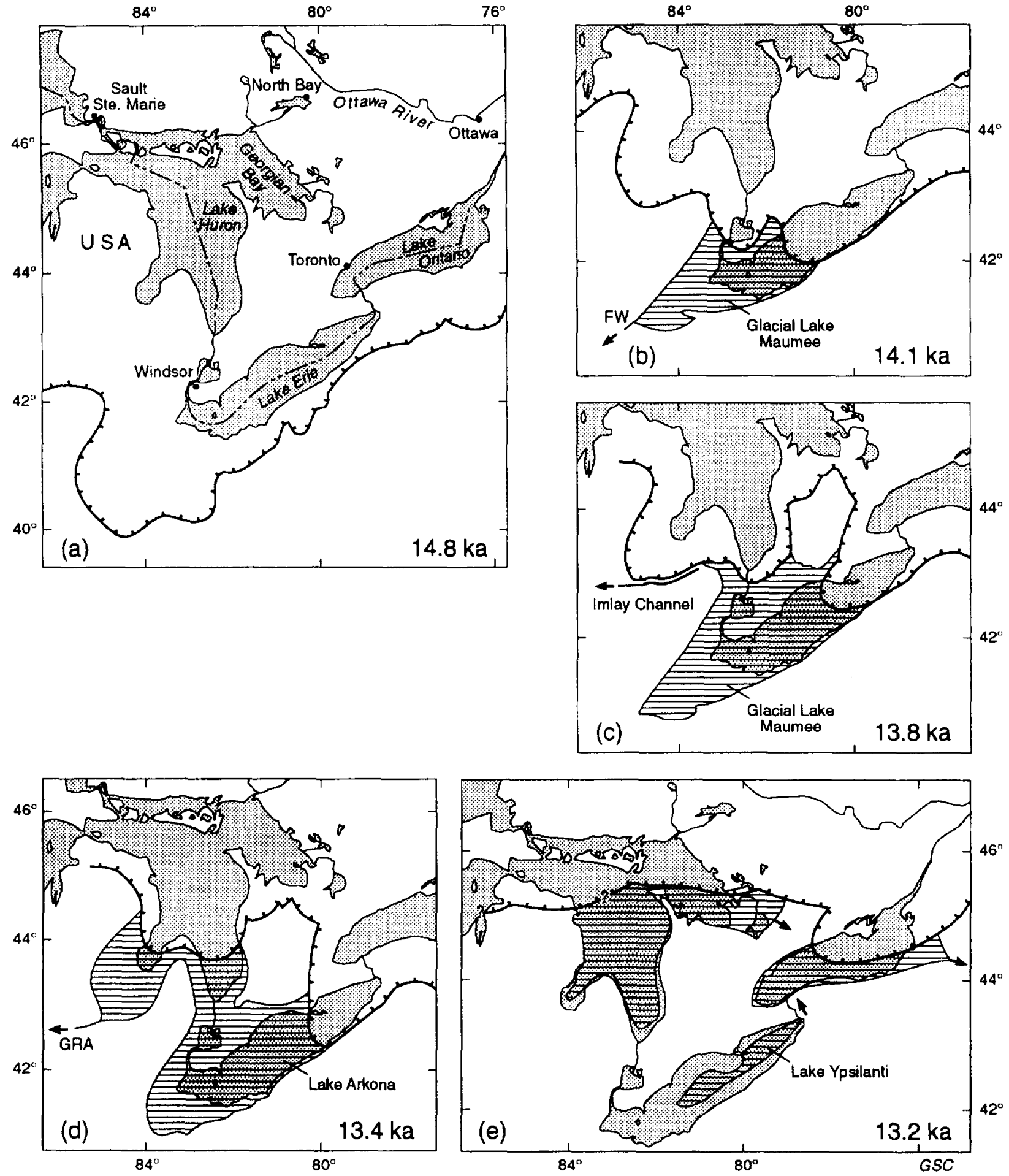

FIG. 4. Maps of ice margins and proglacial lake shorelines during ice retreat from the Port Bruce Stade maximum to the Mackinaw Interstade minimum positions: (a) Port Bruce Stade ice margin maximum at $14.8 \mathrm{ka}$ BP drains without impoundments to Gulf of Mexico (after Barnett, 1992); (b) highest Lake Maumee about 14.1 ka BP, drainage past Fort Wayne (FW) to Mississippi River (after Eschman and Karrow, 1985); (c) final phase of Lake Maumee about $13.8 \mathrm{ka}$ BP drainage to the Michigan basin and Mississippi River via the Imlay channel south of Saginaw Bay (after Barnett, 1992); (d) Early Lake Arkona about $13.4 \mathrm{ka}$ BP impounded in the Huron and Erie basins, drainage to the Michigan basin via the Grand River Valley (GRA); (e) low level lakes about 13.2 ka BP during the Mackinaw Interstade (after Barnett, 1992).

Huron basin (Fig. 4e). As a consequence of the ice margin being south of the Straits of Mackinac (MAC, Fig. 2) (Larson et al., 1994), there was no drainage or circulation between the Huron and Michigan basins at this time. Relatively low lake levels may have existed in the
Huron basin with drainage through the isostatically depressed Fenelon Falls outlet (FF, Fig. 2) to the Ontario basin and the North Atlantic via the Mohawk Valley (MOH, Fig. 2) (Fig. 4e) (Barnett, 1992, but see Fullerton, 1980). 

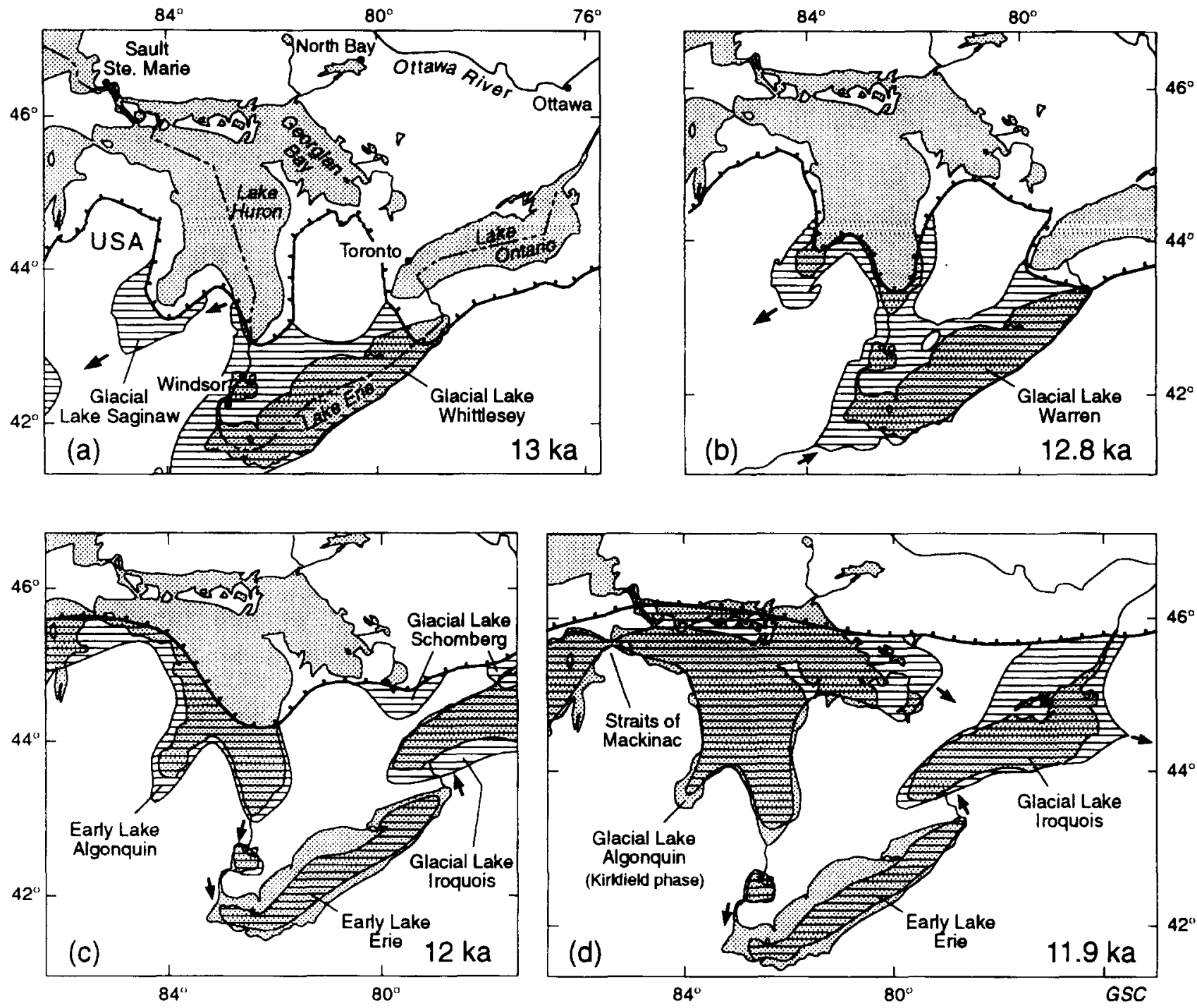

FIG. 5. Maps of ice margins and proglacial lake shorelines during ice retreat from the Port Huron Stade maximum to the Two Creeks Interstade minimum positions: (a) glacial Lakes Whittlesey and Saginaw about $13 \mathrm{ka}$ BP draining to the Michigan basin; (b) highest Lake Warren about 12.8 ka BP, drainage to the Michigan basin (after Eschman and Karrow, 1985); (c) Early Lake Algonquin and Lake Schomberg about 12 ka BP (after Eschman and Karrow, 1985); (d) early Kirkfield phase of Lake Algonquin about $11.9 \mathrm{ka} \mathrm{BP}$.

\section{Ice Retreat to the Two Creeks Interstadial Position $(11.9 \mathrm{ka} \mathrm{BP})$}

Advance of ice about $13 \mathrm{ka}$ BP closed the Mackinaw Interstade. This advance to the Port Huron Stade limit filled the Huron basin with ice, damming glacial Lake Whittlesey against the drainage divide. Lake Whittlesey outflow passed westward south of the ice to glacial Lake Saginaw and thence to the Michigan basin and the Mississippi River (Fig. 5a). With retreat of ice from the Port Huron maximum, lake phases expanded forming the Warren (Fig. 5b), Wayne, Grassmere and Lundy phases. Finally, about $12.5 \mathrm{ka}$ BP, Early Lake Algonquin formed in the Huron basin with a correlative Lake Schomberg in the southern Georgian Bay basin while glacial Lake Iroquois developed in the Ontario basin (Fig. 5c) (Eschman and Karrow, 1985; Barnett, 1992).

Lake Warren phase, and Lake Wayne (a slightly lower phase), drained to the Michigan basin and Mississippi River via the Grand River valley (GRA, Fig. 2) (Fig. 5b).
Lake Grassmere drained eastward to the Ontario basin and the Mohawk River valley (MOH, Fig. 2) to the North Atlantic Ocean. The subsequent Lake Lundy drained to the Michigan basin via the Indian River lowland (IND, Fig. 2). In the next phase, Early Lake Algonquin, drainage reverted again to the east, via Early Lake Erie to Lake Iroquois (Fig. 5c), the Mohawk River valley (MOH, Fig. 2), and the North Atlantic. Depending on position of the retreating ice margin, Lake Schomberg drained south to the Ontario basin then east to Early Lake Algonquin in the Huron basin (Fig. 5c) (Eschman and Karrow, 1985; Barnett, 1992).

Shortly after formation of glacial Lake Iroquois and Early Lake Algonquin, ice retreat in central Ontario opened a lower outlet at Fenelon Falls (also called Kirkfield outlet) (FF, Fig. 2), initiating the Kirkfield phase of Lake Algonquin (Eschman and Karrow, 1985; Finamore, 1985). This low-level Kirkfield phase extended into Michigan basin via the Straits of Mackinac (Fig. 5d) (the Two Creeks low phase, 12-11.8 ka BP, of Hansel 
et al., 1985; Broecker and Farrand, 1963; Fullerton, 1980). The Kirkfield phase drained through Fenelon Falls outlet (FF, Fig. 2) to glacial Lake Iroquois (Eschman and Karrow, 1985) and the North Atlantic Ocean, probably via the Mohawk and Hudson River valleys (Figs 1 and 2).

\section{Huron Basin Lakes Following the Two Creeks Interstade}

The Greatlakean ice advance which followed the Two Creeks Interstade was restricted mainly to the Michigan basin and northwestern Huron basin (Burgis and Eschman, 1981). It closed the Straits of Mackinac and Indian River lowland (MAC and IND, respectively, Fig. 2) so the Michigan basin drained southward to the Mississippi River. Though the ice margin position is poorly constrained, the ice may not have advanced greatly in the eastern Huron basin. The low-level Kirkfield phase of Lake Algonquin may have continued to drain to Lake Iroquois and the North Atlantic Ocean (Fig. 6a), probably via glacial Lake St. Lawrence, in the Upper St. Lawrence and Lake Champlain basin, and via the Hudson River (Fig. 1) (Barnett, 1992; Rodrigues and Vilks, 1994).

When retreat of ice following the Greatlakean advance opened the Straits of Mackinac after 11.2-11 ka BP (Prest, 1970; Hansel et al., 1985; Karrow, 1987), the Kirkfield phase of Lake Algonquin in Huron basin expanded into the Michigan basin. The Kirkfield phase continued to drain via Fenelon Falls (FF, Fig. 2), by this time. to Early Lake Ontario and Champlain Sea (Fig. 6b). A portion of the outflow from this phase may also have drained via the Port Huron outlet (PH, Fig. 2) to account for the light $\delta^{18} \mathrm{O}$ composition of ostracodes in Early Lake Erie (Lewis and Anderson, 1992).

Transition to the Main Lake Algonquin phase occurred about $11 \mathrm{ka} \mathrm{BP}$ as continuing uplift of the Fenelon Falls outlet (FF, Fig. 2) caused transfer of lake drainage to Port Huron (PH, Fig. 2) (Eschman and Karrow, 1985; Finamore, 1985). This was accompanied by retreat of ice in the Superior basin, expansion of Lake Algonquin and the onset of inflow from glacial Lake Agassiz (Teller and Thorleifson, 1983, 1987; Tinkler et al., 1992) (Fig. 6c). Regional climatic cooling, evidenced in the pollen record of vegetation growth around the Great Lakes, has been attributed to the presence of large lakes during this and a later diversion of drainage from central North America (Lewis and Anderson, 1989, 1992; Anderson and Lewis, 1992).

Since first recognized and named by Spencer (1891), the (Main) Algonquin shore has been mapped in both the Huron and Michigan basins by the collected contributions of many investigators (e.g. Goldthwait, 1907, 1908, 1910; Leverett and Taylor, 1915; Johnston, 1916; Stanley 1936, 1937; Deane, 1950; Chapman, 1954, 1975; Harrison, 1972; Karrow et al., 1975; Karrow, 1987; Futyma, 1981; Warner et al., 1984; Kaszycki, 1985; Finamore, 1985; Cowan, 1985). Recent compilations of shore survey sites and isobases of the Algonquin water- plane are available in Walcott (1972) and Lewis and Anderson (1989).

An innovative and alternate interpretation of the Lake Algonquin phases has been developed by Larsen (1987). This assumes the trends of modern crustal movement were also valid in Algonquin time. Also, no assumptions are made concerning the age of former shore features. The resulting reconstruction leads to separate (successive) lake phases for the 'Algonquin' shorelines in the Huron and Michigan basins, respectively. While this possibility should be kept in mind, we have chosen to follow the classical approach in which the shoreline identified as 'Algonquin' by previous workers is regarded as contemporaneous in both basins and the isobases drawn on its waterplane (Lewis and Anderson, 1989, Fig. 2a) are the basis for correlating former shorelines and outlets and for reconstructing the Algonquin lake phases. This choice is supported by the similarity of the available age data (10.5-10.7 ka BP) for the Algonquin shore in the southeastern Huron basin (sites 1, 2 and 3 in Table 1 and Fig. 2) and in the area north of the Michigan basin (sites 10, 12 and 13 in Table 1 and Fig. 2). Furthermore, the isobase trends on modern and late glacial crustal movement need not be identical; they can vary significantly depending on the magnitude, rate, and pattern of glacial unloading as shown by numerical modelling experiments in Clark et al. (1994).

Ice retreat north of Fenelon Falls (FF, Fig. 2) expanded Lake Algonquin which had existed in this region for at least 560-784 years based on varve counts (Finamore, 1985). Ice recession from the highland south of North Bay (Fig. I and NB, Fig. 2) removed the ice dam that supported Main Lake Algonquin starting about $10.5 \mathrm{ka}$ BP, initiating drainage to the Ottawa River valley (OTT, Fig. 2) and Champlain Sea (Fig. 1). The Huron basin water then descended through the Post Algonquin lake phases (Ardtrea, Upper and Lower Orillia, Wyebridge, Penetang, Cedar Point and Payette whose shorelines were mapped and defined by Stanley (1936) and Deane (1950) in the southern Georgian Bay and Lake Simcoe areas, Fig. 2). Two further lower phases, the Korah and Sheguiandah, were recognized by Hough (1958) at Sault Ste. Marie (Fig. 1) and on Manitoulin Island (Fig. 2). These Post Algonquin lakes were controlled at a series of outlets exposed by the retreating ice south and southeast of North Bay (PET to NB, Fig. 2) (Chapman, 1954; Harrison, 1970, 1972; Ford and Geddes, 1986). On the basis of Stanley's (1936) measurements of shoreline tilt, Hough (1958) noted that 19\% of post-Main Algonquin uplift had been achieved by Payette time. Assuming a Main Algonquin age of 10.5-10.7 ka BP, this amount of uplift translates to an age of 9.9-10.2 ka BP for the Payette phase (see Appendix for expressions relating time to uplift). Apart from this estimate, specific ages of the Post Algonquin shorelines are not available.

\section{Huron Basin Lakes During and Following the North Bay Interstade}

After the Algonquin drawdown, water of the north- 

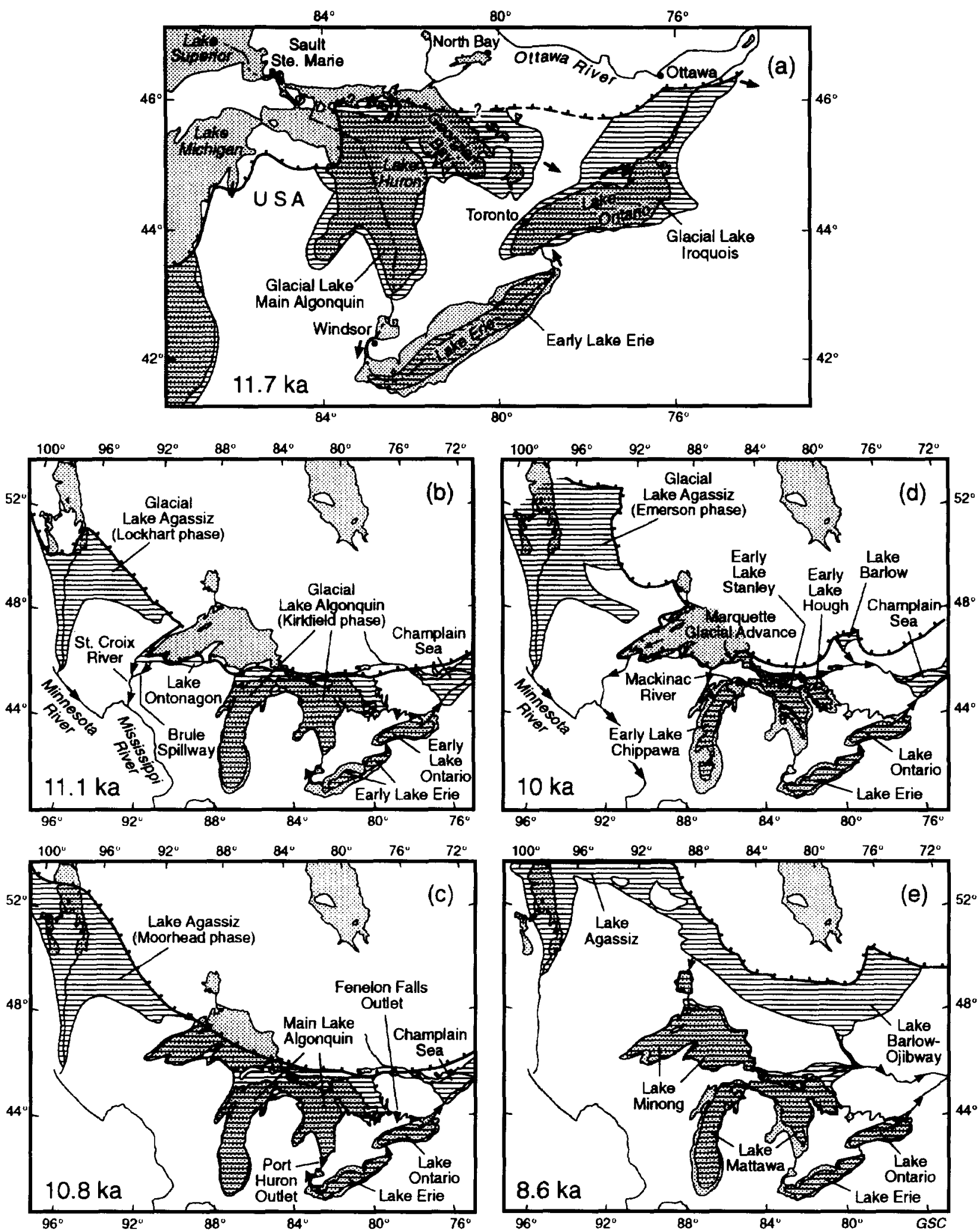

FIG. 6."Maps of ice margins and lake shorelines following the Two Creeks Interstade: (a) Kirkfield phase of Lake Algonquin in the Huron basin during the Greatlakean Stade about $11.8 \mathrm{ka}$ BP (after Barnett, 1992); (b) late Kirkfield phase of Lake Algonquin in the Huron and Michigan basins about $11.1 \mathrm{ka}$ BP; (c) Main Lake Algonquin in the Huron, Michigan and Superior basins about $10.8 \mathrm{ka} \mathrm{BP}$; (d) low lakes during the Ottawa-Marquette phase about $10 \mathrm{ka}$ BP; (e) Lake

Mattawa high phase about $8.6 \mathrm{ka} \mathrm{BP}$. (Maps 6b-6g after Lewis and Anderson, 1989.)

eastern Huron basin was first held up by a morainic dam across the Ottawa River valley near Deux Rivières, Ontario, about $30 \mathrm{~km}$ east of Mattawa (Fig. 1). A rock sill at nearby Aylen controlled lake levels in both the
Nipissing-Mattawa-Ottawa lowland and in glacial Lake Barlow (expanding with ice retreat up the Upper Ottawa-Timiskaming basin) (Vincent and Hardy, 1979; Veillette, 1988; Barnett, 1992). These levels were likely 

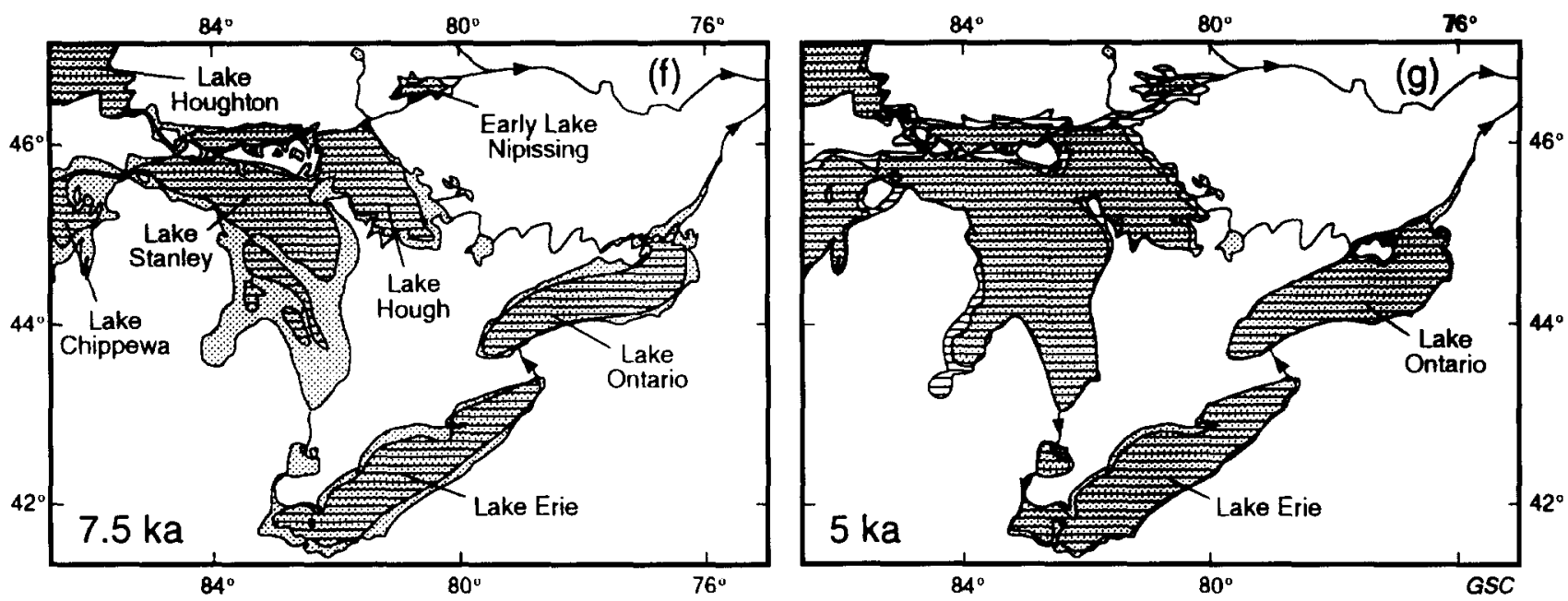

FIG. 6. Maps of ice margins and lake shorelines following the Two Creeks Interstade: (f) post-Mattawa low or onset of the Nipissing transgression about $7.5 \mathrm{ka} \mathrm{BP}$; (g) Nipissing Great Lakes about $5 \mathrm{ka}$ BP. (Maps 6b-6g after Lewis and Anderson, 1989.)

too low to backflood into the Georgian Bay and northern Huron subbasins where local sills would have come into effect (shoreline diagram, Fig. 7a, in Lewis and Anderson, 1989). A basal gyttja date from Morel Lake in the Mattawa River (Fig. 2) valley (Harrison, 1972) suggests the morainic dam was breached and lake levels were definitely lowered to local sills in the Huron basin by $10.1 \mathrm{ka} \mathrm{BP}$, forming Lake Hough in the Georgian Bay subbasin and Lake Stanley in the northern Huron subbasin (Hough, 1962; Lewis, 1969; Prest, 1970; Chapman and Putman, 1984; Eschman and Karrow, 1985; Barnett, 1992) and Lake Chippewa in the Michigan basin (Hough, 1955, 1958). Hough (1958, 1962), Larsen (1987) and Colman et al. (1994a) reconstructed post-Algonquin lakes in the Lake Michigan basin using the North Bay outlet sill as a control of the water levels. However, an analysis of this and other possible thresholds (Lewis and Anderson, 1989; Fig. 7c) showed that the North Bay outlet sill (Taylor, 1897) initially controlled local lakes in the Lake Nipissing basin only. The North Bay sill did not rise enough to control lakes in the Georgian Bay, northern Huron, or Michigan basins until about $8 \mathrm{ka} \mathrm{BP}$; until then, low water levels in these basins were controlled locally at the levels of the lowest points on the rims of each basin where overflow occurred. Highstands, however, may have coalesced into a single level in all these basins, when high flows, augmented by discharge from Lake Agassiz and Lake Barlow-Ojibway, were backed up by hydraulic damming at constrictions in the Ottawa River valley. New information bearing on interpretation of the lowstands is reviewed later

The breaching of the Deux Rivières dam, in combination with the Marquette ice advance across the Superior basin at $10 \mathrm{ka} \mathrm{BP}$, which diverted Agassiz drainage from the Great Lakes basin, initiated the Ottawa-Marquette low phase in the Huron basin (Fig. 6d). The period of lake damming by the Laurentide ice ended with the Post Algonquin drawdown. However, lakes in the Huron basin continued to be influenced for a further 2000 years by inflows from the Superior basin and the northern glacial lakes Agassiz and Barlow-Ojibway. Hydraulic resistance in constrictions of the Ottawa River valley downstream from its junction with Mattawa River is thought to have raised and controlled Huron-basin and Michigan-basin lake levels during subsequent periods of high inflow from either Agassiz or Barlow-Ojibway basins (Fig. 1) (Lewis and Anderson, 1989).

Retreat of ice from the Superior and Nipigon basins permitted glacial Lake Agassiz to flood eastward, starting about $9.5 \mathrm{ka} \mathrm{BP}$, through a series of outlets at successively lower levels into the Superior and Huron basins (Teller and Thorleifson, 1983, 1987). Further retreat allowed Agassiz to drain into glacial Lake Ojibway before collapse of the Laurentide ice about $8 \mathrm{ka}$ BP ended these northern proglacial lakes. Thus, for at least 1500 years during the Mattawa phase (Fig. 6e) of widely-varying lake levels and water properties (discussed later), fluctuations in outflow from the entire southern Laurentide ice front from western Canada to eastern Quebec influenced the Huron basin, either by direct flooding via the Superior basin or by backflooding from hydraulic constrictions in the Ottawa Valley downstream of its junction with the Nipissing-Mattawa lowland.

After the collapse of Laurentide ice and drainage of Lakes Agassiz and Ojibway to Hudson Bay after $8 \mathrm{ka}$, the water supply to the Huron basin was limited to local sources, and lakes fell to relatively low levels in each of the subbasins of the Huron basin (Fig. 6f). The reduced outflow was controlled at the Trout Lake sill near North Bay (NB, Fig. 2) (Taylor, 1897). Continuing differential uplift of this outlet control raised these non-glacial lakes throughout the Huron basin, ultimately backflooding into both the Michigan and Superior basins. Eventually, drainage from the Nipissing Great Lakes (Fig. 6g) was diverted southward to the Mississippi River via outflow at Chicago to the Illinois River valley (Fig. 1) and to Lake Erie via Port Huron from about 5.7 to $4.7 \mathrm{ka}$ (Dreimanis, 1958; Lewis, 1969; Terasmae, 1979; Karrow, 1980; Monaghan et al., 1986; Eschman and Karrow, 1985). Later downcutting of the Port Huron outlet 


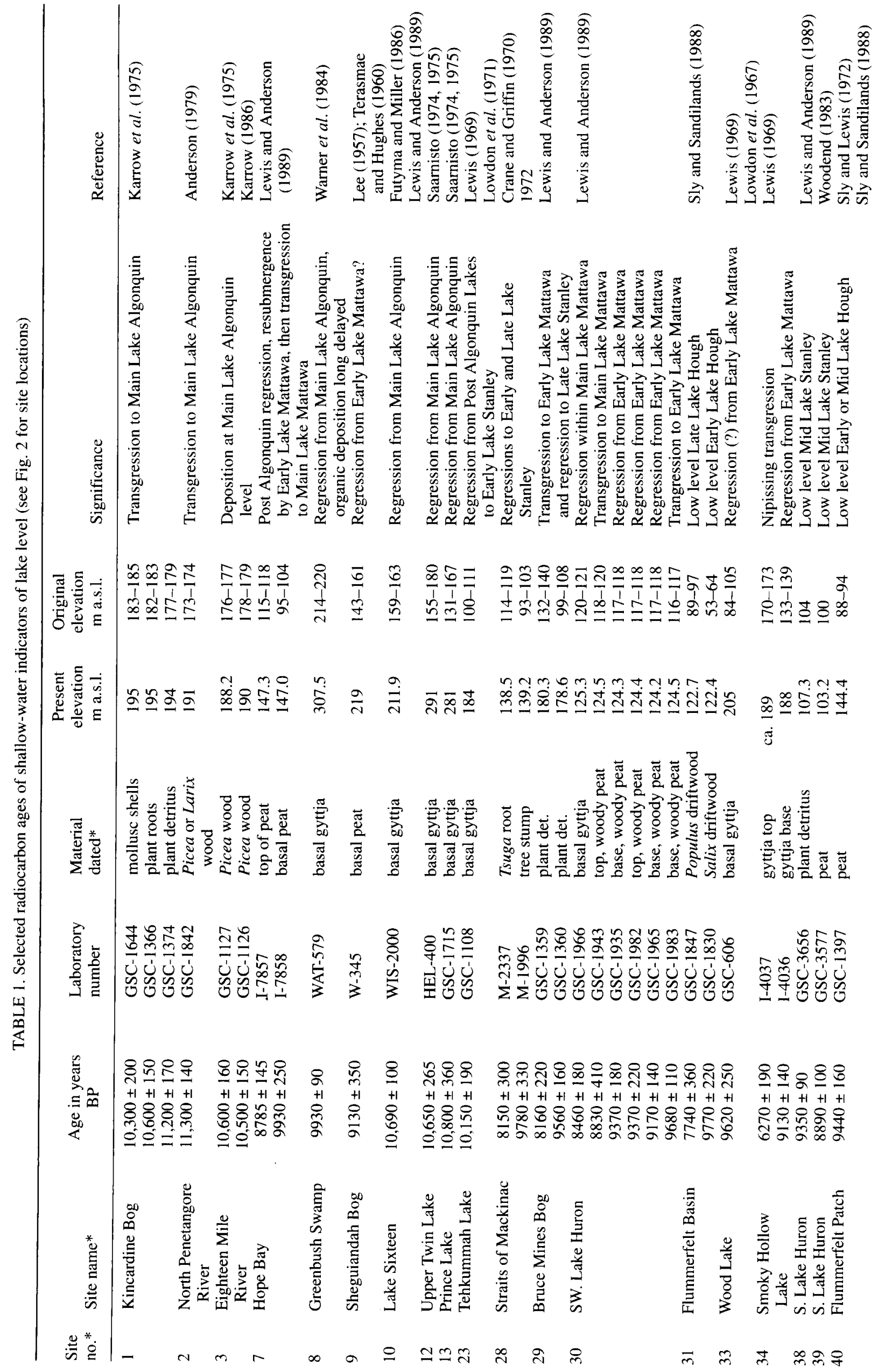




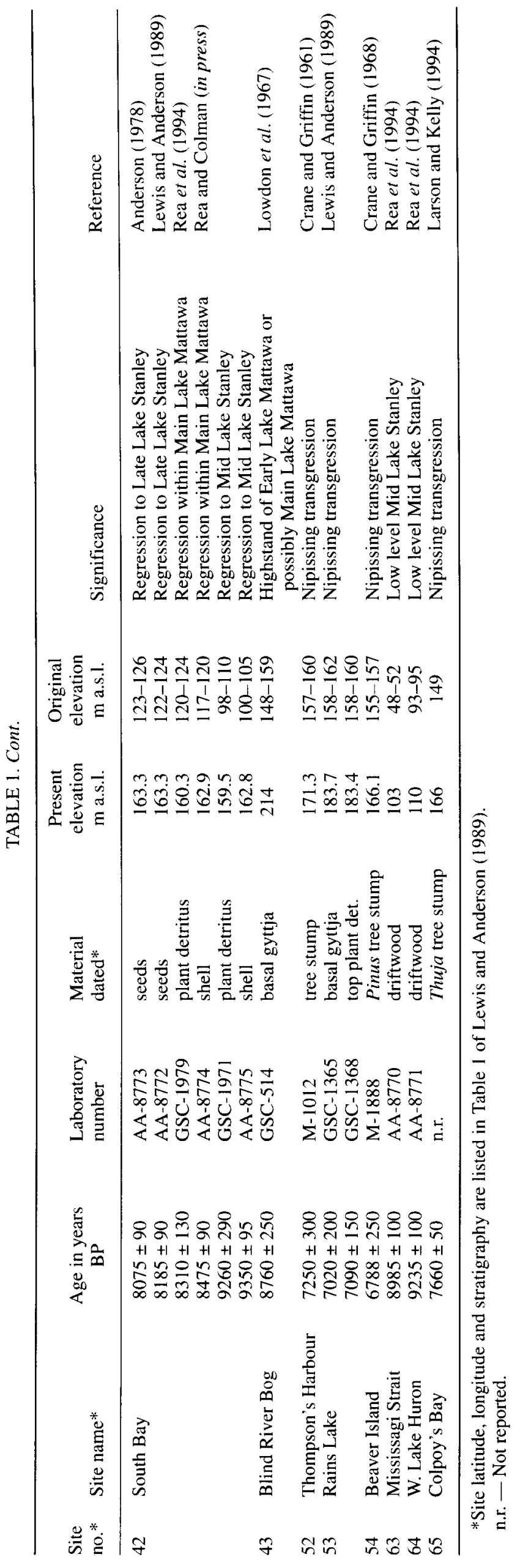


brought the Great Lakes to their present drainage configuration. The Nipissing shore is well developed, commonly appearing as a beach and shoreface below a distinct wave-cut bluff. Its elevation has been measured in many places (Goldthwait, 1907, 1908, 1910; Leverett and Taylor, 1915; Stanley, 1936, 1937; Deane, 1950; Farrand, 1960; Lewis, 1969, 1970; Cowan, 1978, 1985; Karrow, 1980, 1987; Lewis and Anderson, 1989) and isobases on the inferred Nipissing waterplane constitute a useful measure of crustal warping in the Huron basin since about 5 ka BP.

\section{SUBGLACIAL MELTWATER OUTFLOWS}

Subglacial meltwater flows have affected the Huron basin directly but the timing of these events is either unknown or poorly known. Bedrock potholes high on the northern slopes of Huron basin were early recognized by Stanley (1934) as evidence of erosive meltwater flows. A $70 \mathrm{~km}$ wide band across northern Georgian Bay shows evidence of severe erosion and sculpting by high velocity turbulent flows estimated at $10^{7} \mathrm{~m}^{3} \mathrm{sec}^{-1}$ and attributed to a large outburst of subglacial meltwater (Kor et al., 1991). Erosion of a buried valley complex between the Georgian Bay and Ontario basins is interpreted as a result of catastrophic release of subglacial meltwater during the Mackinaw Interstade (Barnett, 1990, 1992). Offshore evidence for the deposition of sediment from these flows is not yet recognized.

Subglacial meltwater discharge during retreat of ice in northwestern Ontario may have affected inflows to the downstream Huron basin. Sharpe and Cowan (1990) have suggested that gravel-dominated moraines in this area originated during episodes of enhanced glaciofluvial sedimentation. Large volumes of meltwater and winnowed silt and clay would drain to downstream lake basins during formation of the gravel moraines (Thorleifson and Kristjansson, 1993). If charged with carbonate rock flour from Hudson Bay lowland limestones or carbonate drift on the Canadian Shield, these waters could contribute enhanced dissolved solids (and hard-water effect to radiocarbon dates of carbonate shells) in the Huron basin.

\section{SEDIMENTS AND LAKE HISTORY}

\section{Introduction}

The sediments of the Great Lakes, particularly their grain size distributions, are responsive to changing lake levels (water depths) and associated sedimentary inputs (Thomas et al., 1973; Sly, 1978; Rea et al., 1981; Colman et al., 1994a). In deeper subbasins, the sediments constitute a continuous record, and their fossils provide information about former paleoenvironmental conditions. The morphology of subbasins and the distribution of surficial sediments are described by Thomas et al. (1973) for Lake Huron and by Thomas (1988) for Georgian Bay.

The sedimentary records commonly found in the deep offshore areas of northern Lake Huron consist of a conformable sequence of reddish-brown laminated to varved clay overlain by grey banded silty clay. In 1962, Hough examined sediment sequences in 76 cores from northwestern Lake Huron in water depths ranging from 44 to $133 \mathrm{~m}$. He identified an unconformity in the upper $1.5 \mathrm{~m}$ which, in water depths less than $70 \mathrm{~m}$, is characterized by a thin sand zone with shallow-water mollusc shells between grey clay above and red clay below. The unconformable zone was traced into deeper water as a silt zone within the grey clay. The coarse unconformable zone was interpreted as evidence for the 'Stanley low-water stage of the lake', a low level phase predicted by Stanley $(1936,1938)$ to have immediately followed the Post Algonquin drawdown upon the opening of the isostatically depressed North Bay outlet. The prediction was based on the projection of Post Algonquin shorelines to successively lower elevations well below any known outlet at the time, and was substantiated by the finding of a submerged valley in the Straits of Mackinac which was thought to have carried discharge from a low level lake in Michigan basin (later identified by Hough (1955, 1958) as Lake Chippewa) to Lake Stanley in the Huron basin. The presence of the unconformity was confirmed subsequently by Graham and Rea (1980) in northern Lake Michigan and northwestern Lake Huron, although evidence of a corresponding lowstand was not identified in western Lake Huron. Anderson and Lewis (1974) found plant detritus deposits that signified correlative low lake levels in southwestern Lake Huron. Tovell et al. (1972) presented evidence of low-lake erosion on the Deane Saddle (Fig. 2) between Lake Huron and Georgian Bay.

Teller (1985) reviewed the sequence of deepwater sediments from northwestern Lake Huron but found no units which he could clearly relate to periods of Agassiz inflow. He surmised that much of the influx (and effect) from the Superior basin may have bypassed the main Huron basin spilling eastward via North Channel, north of Manitoulin Island, toward the lake outlet and Ottawa River valley.

The sedimentary sequence of northwestern Lake Huron (Mackinac basin) has been re-examined in acoustic reflection records, and in cores, one of which was analyzed for pollen content by Zilans $(1985,1991)$. A thick ( $>35 \mathrm{~m}$ ) variegated sequence of predominantly reddish-brown 'glaciolacustrine' clay overlies grey sand and grey-brown or red sandy-silt to silty-sand till and comprises, from bottom to top, units of (1) thick-bedded sandy clay and silt at the base, (2) thinly laminated and mottled clay, and (3) thickly (in places, thinly) laminated clay in the upper part with occasional bands of silt and of bright red clay as noted by Hough (1962). The general intensity of red coloration of the reddish-brown units diminished eastward in the Huron basin. The 'glaciolacustrine' sequence underlies 'postglacial' thinly laminated clay under homogeneous and black FeS-banded grey silty clay, the surficial unit. A pollen zonation, correlated to onshore radiocarbon-dated sequences, suggests a 10.2 $\mathrm{ka} \mathrm{BP}$ age for the top of 'glaciolacustrine' clay, and a 6.2 
ka BP age for the top of the 'postglacial' thinly laminated clay. Zilans $(1985,1991)$ also verified Hough's Lake Stanley unconformity, commonly forming the upper contact or truncating the thickly laminated clay above. The shallow water molluscan fauna associated with the unconformity was found to consist of species now found predominantly in water depths less than $15 \mathrm{~m}$.

The thickly laminated upper 'glaciolacustrine' unit has a coarser grain size than the underlying clay and contains reddish brown and grey laminae. It contains the regional spruce-pine pollen transition, and most likely represents late Main Algonquin and early post-Algonquin sedimentation on the basis of this pollen 'age'. The total carbonate contents of the red and grey laminae of the thinly laminated 'glaciolacustrine' unit are similar (10-20\%), but calcite dominates in the red layers and dolomite in the grey layers. Overall, the 'glaciolacustrine' unit accumulated rapidly, estimated at about $2.3 \mathrm{~cm} / y e a r$ from the inferred ages of regional pollen zone boundaries.

The overlying, thinly laminated, 'postglacial' grey clay contains sections of tricolor banding comprising units of dark grey, olive grey and dusky red with indistinct boundaries. An occasional black FeS band occurs in places. On echograms $(14.25 \mathrm{kHz})$ correlated to cores, the thinly laminated section of 'postglacial' grey clay is characterized by faint, closely spaced, discontinuous reflections. This unit contains a record of relatively sparse pollen content and a moderately high sedimentation rate $(2.8$ decreasing to $0.6 \mathrm{~mm} /$ year), suggesting significant sediment influx. Carbonate contents are lower (1-10\%) than in the underlying 'glaciolacustrine' unit. In the overlying surficial grey clay, the carbonate contents are near zero and the sedimentation rates decline to about $0.3 \mathrm{~mm} /$ year or less (Zilans, 1985, 1991), reflecting lesser influx during subsequent phases (Graham and Rea, 1980).

A sedimentary sequence about $6 \mathrm{~m}$ thick in northeast- ern Georgian Bay, described by McAtee (1977), is similar. There, a thick series of variegated, laminated clays, dominantly greyish brown in color, overlies sand and till and underlies dark grey silty clay, the lower part of which is faintly laminated. The spruce-pine pollen transition occurs at the change from brown to grey sediment. Average sedimentation rates, based on inferred ages of pollen zone boundaries, are highest for the brown clay section (ca. $5 \mathrm{~mm} /$ year), medium for the lower part of the grey silty clay $(0.9-1 \mathrm{~mm} / \mathrm{year})$ and lowest in the surficial unit of grey silty clay $(0.5 \mathrm{~mm} /$ year $)$. Based on the pollen zonation age, the brown clays are likely a glaciolacustrine facies of Lake Algonquin. The lower section of postglacial grey clay, of moderately high sedimentation rate, contains sporadic peaks in spruce pollen concentration, and probably represents influx during the Mattawa phase.

\section{Offshore Indicators of Lake Level Change}

\section{Seismo- and litho-stratigraphy}

A recent study (Moore et al., 1994; Rea et al.,1994) shows regional reflectors in $3000 \mathrm{~km}$ of high-resolution broadband $(2-8 \mathrm{kHz})$ seismic reflection profiles. These reveal at least 9 depositional sequences in the lacustrine sediments of northern Lake Huron and Georgian Bay (Fig. 7). The reflectors are named informally by color; below the sediment surface, they are: Light Blue, Upper Light Green, Lower Light Green, Yellow 1, Yellow 2, Orange, Dark Green and Dark Blue (Fig. 7). The reflectors signify a process of widespread erosion as each truncates older sequences in shallower water on the margins of the basin. Synthetic seismogram analyses, based on physical properties of the sediments in cores, show the reflectors are mainly caused by bulk density changes which correlate, in turn, with intervals of increased mag-

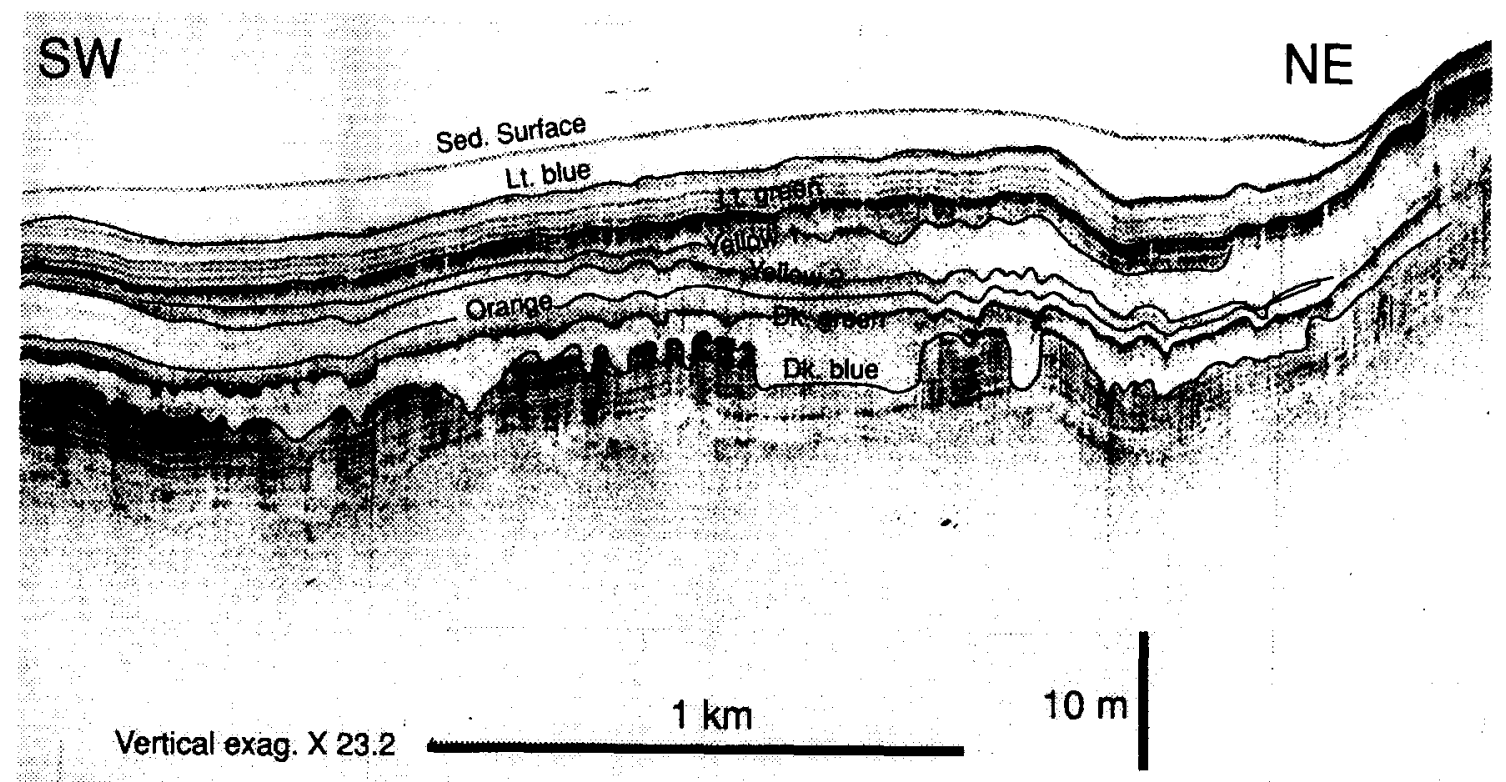

FIG. 7. High-resolution seismic reflection profile from northern Lake Huron showing subsurface regional reflectors and their informal 'color' names. The Light Green reflector is actually a closely spaced couplet comprising an Upper Light Green and a Lower Green reflector (from Moore et al., in press). 
netic susceptibility and coarser grain size (Moore et al., 1994).

The regional reflectors in seismic profiles are interpreted as episodes of lower lake level. The intervals of coarser grain size, in depositional basins away from the eroded basin margins where the sedimentary sequences represent continuous time series, are taken to represent the durations of the lowstands (Moore et al., 1994). This is consistent with the observed primary dependence of surface sediment grain size on water depth in the present Lake Huron in which reduced water depth correlates to coarser grain size (Thomas et al., 1973).

An alternate interpretation might be that the reflectors were formed during periods of catastrophic flooding of glacial Lake Agassiz into the Superior and downstream basins of the Great Lakes drainage system (Teller and Thorleifson, 1983, 1987; Teller, 1985). Under these conditions of high flow and higher lake level one might also expect increased lake turbulence and the formation of zones of coarser grain size (reflectors). However, the lowstand reflector interpretation is consistent with recognized periods of lowered lake level and terrestrial emergence on the north shore of Lake Huron, for example, at $9.6 \mathrm{ka}$ BP near Bruce Mines (Fig. 2, site 29) and $9.3 \mathrm{ka}$ BP at South Bay (Fig. 2, site 42) (Lewis and Anderson, 1989). As shown in later sections, it is consistent with the complete shallow-water record of lake level change. It is also consistent with the original definition of a lowstand in the Huron basin, in which coarse sediment forming the Light Blue reflector directly matches the coarse zone used by Hough (1962) to define low-level Lake Stanley. Our preferred interpretation is that reflectors signify lowered lake levels. As noted by Teller (1985), it is more likely that turbulent flows arising from catastrophic floods from Lake Agassiz were restricted to the North Channel of Lake Huron (Fig. 2).

Our lithostratigraphy is based on 49 cores from 28 sites in northern Lake Huron and Georgian Bay. Collectively, these penetrate most reflectors including the Orange and those above. The uppermost seismic sequence (Surface Sediment sequence), from the lakebed to the Light Blue reflector (Fig. 7), is up to $3 \mathrm{~m}$ thick and consistently comprises grey clay with black banding, topped with $1-2 \mathrm{~cm}$ of brown oxidized sediment. The base of the sequence becomes uniformly dark grey (Rea et al., 1994b). The sequence is generally equivalent to the upper part of the 'postglacial' grey clay of Zilans (1985, 1991) and the upper part of the dark grey silty clay of McAtee (1977).

The Light Blue sequence, from the Light Blue to the Upper Light Green reflector (Fig. 7), ranges $1-3 \mathrm{~m}$ in thickness and is a transition from the overlying grey clays to the underlying reddish-brown units. The transition consists of $10-20 \mathrm{~cm}$ thick layers of pinker and greyer clay which alternate two or three times downcore. Thin color Jaminations similar to the tricolor rhythmites in the underlying units appear in the lower part of the sequence.

The Upper and Lower Light Green sequences, from the Upper Light Green to the Lower Light Green reflec- tor and from the Lower Light Green to the Yellow 1 reflector (Fig. 7), are dominantly reddish-brown clay characterized by tricolor banding, and range $1-4 \mathrm{~m}$ in thickness. The triplets range in thickness between about 0.8 and $2 \mathrm{~cm}$, and the color bands are typically brown over red over grey clay with gradational boundaries. The triplets are possibly varves like the red-grey couplets in the Yellow sequences below. Variability in the sequence is mostly caused by variation in thickness of the red bands which are absent in some varves toward the top of the laminated section. The grey bands are coarser and more poorly sorted than are the brown and red bands. The triplets are somewhat thicker in the lower part of the Light Green sequences. The Light Green and Light Blue sequences together appear to be equivalent to the thinly laminated 'postglacial' clay of Zilans $(1985,1991)$ and the lower part of the dark grey silty clay of McAtee (1977).

The Yellow sequences, from the Yellow 1 to the Yellow 2 reflector and from the Yellow 2 to the Orange reflector (Fig. 7) are up to $3 \mathrm{~m}$ thick. They are characterized by pronounced grey over red clay couplets, interpreted as varves, representing annual cycles of deposition. The red bands rest on a sharp boundary and grade (inversely) upward into coarser, more poorly sorted grey clay. Rare black sulphide bands occur a third- to half-way up the red intervals, and may reflect a reducing zone corresponding to the spring bloom of planktonic growth. The couplet thicknesses vary systematically, from 1-10 $\mathrm{cm}$ mostly because of red band variability, on a 11 or 22 layer (year) cycle. The red bands contain slightly more carbonate and have a distinctly higher calcite/dolomite ratio than the grey bands (Zilans, 1985, 1991). The color bands are thought to represent input from different sediment sources at different times of the year. These sequences appear to be equivalent to the thickly laminated 'glaciolacustrine' clay of Zilans $(1985,1991)$ and the upper part of the greyish-brown variegated, laminated clay of McAtee (1977). However, Zilans (1985, 1991) characterizes the couplets differently, with the coarser grey clay forming the base layer in summer under a finer red clay layer deposited in winter.

The Orange sequence, from the Orange to Dark Green reflector (Fig. 7), was penetrated by only 1 or 2 cores. These suggest the Orange sediments are stiffer and are not obviously banded. They show only subtle variations between pinker and greyer zones (Rea et al., 1994b). This sequence is probably equivalent to the upper part of the thinly laminated and mottled 'glaciolacustrine' clay of Zilans $(1985,1991)$ and part of the greyish-brown. variegated, laminated clay of McAtee (1977).

\section{Age Model for Offshore Sedimentary Events}

The ages of the reflectors and sequences described above were derived by AMS dating of calcite ostracode shells from various levels in 3 offshore sediment cores (Rea et al., 1994b). Cross correlation among these cores and a dated core in southern Lake Michigan (Colman $e t$ 


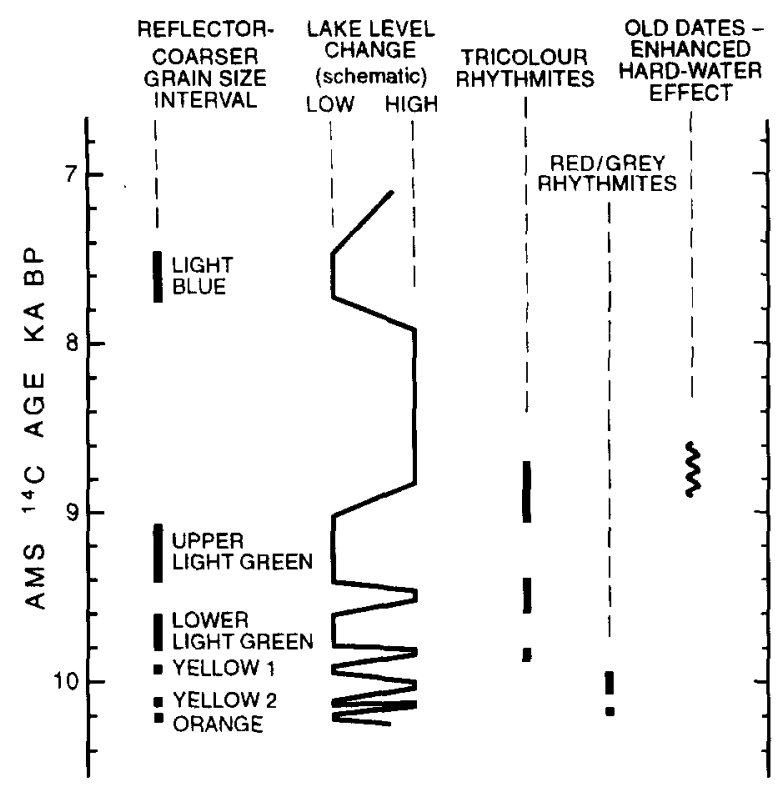

FIG. 8. Plot of age vs. reflectors and coarse sediment zones, lake level changes (lowstands and highstands), core lamination, and enhanced hard-water effect for deep water sediments in the northern Huron basin, based on the age model in Rea et al. (1994b).

al., 1990) resulted in a master time scale (Fig. 8) for a core in northwestern Lake Huron (core 37P, Fig. 2) as discussed in Rea et al. (1994b). The dates were corrected for hard-water effects (apparent ages of $\mathrm{C}$ in the bicarbonate reservoirs of lakes) of 440 years in Lake Huron and 250 years in Lake Michigan based on AMS analysis of modern pre-bomb mollusc shells from these lakes (Rea and Colman, in press). The master core time scale is based on 11 dates. This age model (Fig. 8) is the basis for assigning ages to features and boundaries of zones within the cores for variations in grain size, ostracode assemblages and stable isotope values, the major input for the paleolimnological interpretation of the early Holocene lakes in the Huron basin.

Six additional dates were rejected as 'too old' (800 to 1700 years too old). These 'old' shells all come from a restricted interval dating between 8.6 and $8.9 \mathrm{ka} \mathrm{BP}$ on the master time scale (Fig. 8). If accepted, these dates would imply an unnecessarily complex sedimentary history. Lacking evidence of physical disturbance or reworking, this interval is interpreted as a geochemical anomaly - a time when the Huron basin received water of excessive hard-water effect from relatively more carbonate-rich terrane (Rea et al., 1994b). It seems relevant to note that Thorleifson and Kristjansson (1993) infer an active ice stream flowing toward the northeastern Superior basin at about the time of this anomalously old interval which would have passed over carbonate-rich tills (matrix carbonate of $30 \%$ compared with $10 \%$ or less available in the Nipigon basin to overflowing Lake Agassiz waters (Dredge and Cowan, 1989; Karrow and Geddes, 1987). They further postulate that outwash from this ice stream was responsible for the occurrence of highly calcareous grey varves in Lake Superior sampled by Dell $(1972,1974)$ and Farrand $(1969 a, b)$. Thus, this, or a similar event, might account for the hard-water geochemical anomaly observed in the Lake Huron ${ }^{14} \mathrm{C}$ dates.

\section{Shallow Water (Lake Level) Indicators}

The offshore sedimentary sequences provide continuous time series of changes in lake conditions and levels, but only rarely can they be used to precisely determine former water depths (Colman et al., 1994a). Different data are needed to define the amplitudes of lake level change. Here we examine the record of shoreline, emergence and submergence features, as compiled by Lewis and Anderson (1989), which define shallow water conditions, and hence, former waterplanes and lake levels more closely. A re-interpretation of the lake level history for the northern Lake Huron basin will then be developed which honors both the shallow and deep water data sets, and the uplift history of the lake outlets.

\section{Former shorelines and related sediments}

The two principal shorelines that are recognized and mapped regionally in the northern Huron and surrounding basins consist of the Main Algonquin shore and the well developed Nipissing Great Lakes coastal zone (Figs $6 \mathrm{c}$ and $6 \mathrm{~g}$ ). The best dated sediments related to the Algonquin and Nipissing waterplanes are those in beach settings (Dreimanis, 1958; Lewis, 1969) and in stream terraces and estuarine fill along the eastern side of Lake Huron (Fig. 2); the latter document transgressing water levels from 11.3 to $10.5 \mathrm{ka} \mathrm{BP}$ for the Algonquin phase and 6.2 to $4.2 \mathrm{ka} \mathrm{BP}$ for the Nipissing phase (Karrow et al., 1975; Karrow, 1980, 1986) (Fig. 9). Dating of Nipissing-related sediments at Sault Ste. Marie (Fig. 1) (Cowan, 1978) and North Bay (Fig. 1) (Lewis, 1969) suggest this lake level had abandoned the Nipissing shore in the northern Huron basin by about $4.7 \mathrm{ka} \mathrm{BP}$. Although widely mapped, the age of the northern Algonquin shore is indicated only in the northwestern Huron basin at about $10.7 \mathrm{ka}$ BP based on basal gyttja dates from small lake basins just below the Algonquin level near Cheboygan (site 10, Fig. 2) (Futyma and Miller, 1986; Lewis and Anderson, 1989) and Sault Ste. Marie (sites 12, 13, Fig. 2) (Saarnisto, 1974).

\section{Emergence/submergence and shallow water conditions}

The data for reconstruction of the amplitudes of lake level changes in the northern Huron basin are mostly radiocarbon-dated regressive and transgressive sediment sequences and other indicators of shallow water conditions. Forty-six radiocarbon dates from 27 sites in the Huron basin and immediately adjacent areas of the Georgian Bay, northern Michigan, and eastern Superior basins are utilized (Table 1; Fig. 2). Where more than one age is available from a site, all bear the same site number. The ages were selected for consistency among themselves guided by the regional pollen zonation where available (Lewis and Anderson, 1989).

Most ages apply to the bases of sections of organicrich sediment, such as peat or gyttja from small bog and 

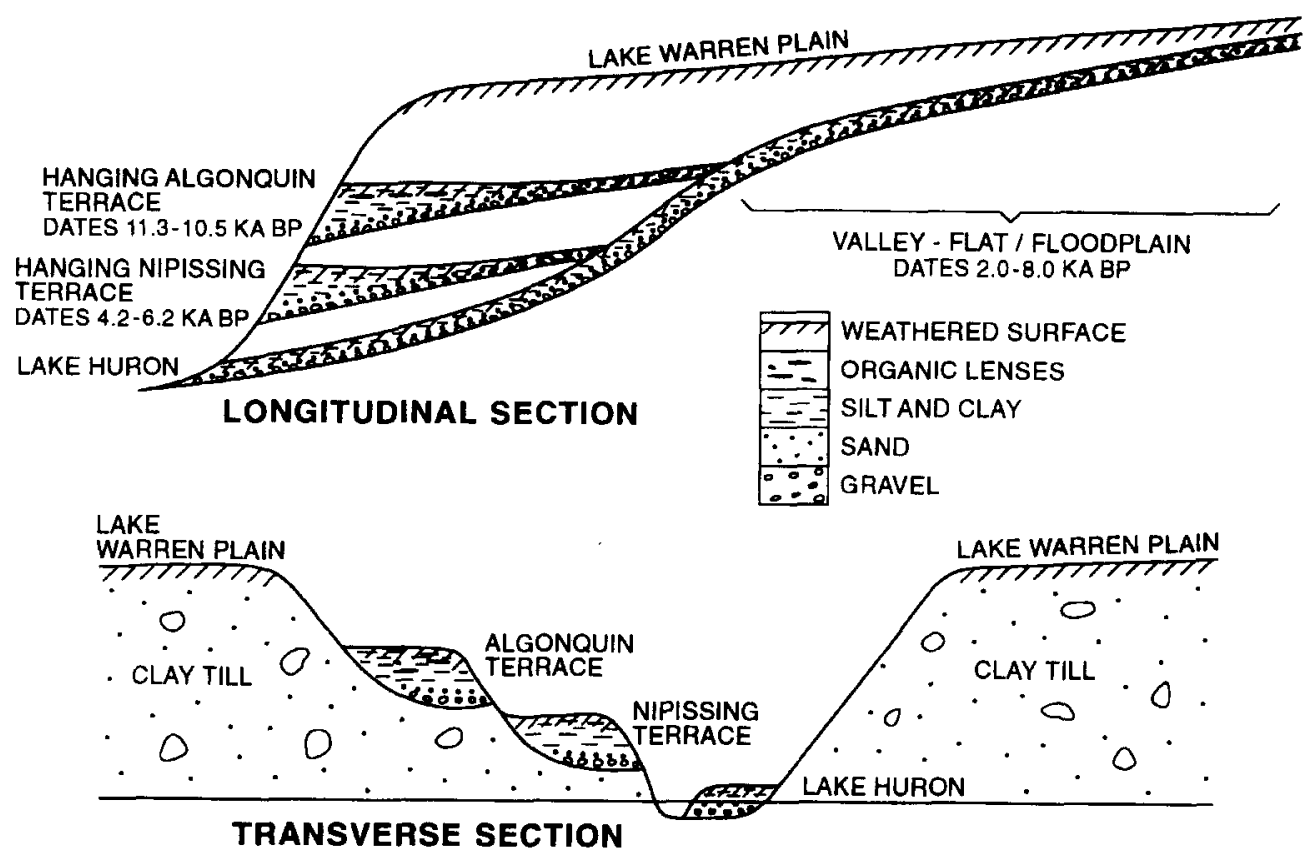

FIG. 9. Summary diagram of dated terrace and estuarine sediments related to the Algonquin and Nipissing lake phases in the southeastern part of the Lake Huron basin (adapted from Karrow, 1986).

lake basins, and organic matter from stream terraces and estuarine deposits. Some occurrences are now submerged below the present lake level. Most data from small lakes signify emergence, i.e. the times at which the large Huron basin waters descended (regressed) below the sill elevation of the sample sites, and sedimentation in the local basins came to be dominated by vegetation or algal production. A date at the top of an organic section in a small lake, estuary or stream terrace buried by mud or sand would signify ascent (transgression) of the large Huron basin lake above the sample site with a switch to inorganic sedimentation dominated by wave- or current-transported clastic grains. A few ages apply to submerged tree stumps or roots in growth position; this evidence requires emergence of the site at the time of tree growth with lake level below the elevation of the roots of the former trees. Other ages apply to sediment-buried driftwood. These signify only that lake levels were higher than the sample site at the time of driftwood deposition.

\section{Reconstruction of original elevations of lake indicators and outlets}

The Huron basin, including all the dated sites, has been and is still being differentially uplifted as a result of glacioisostatic recovery with the result that the altitude relation among shallow-water features, shorelines and lake outlets change with time. This change is well documented by elevation measurements on the formerly level Nipissing and Algonquin shorelines which each rise toward the north-northeast from present elevations of 184 $\mathrm{m}$ in the southern Lake Huron area to 198 (14 m uplift in $5 \mathrm{ka}$ ) and $300 \mathrm{~m}$ a.s.l. ( $116 \mathrm{~m}$ uplift in $10.7 \mathrm{ka}$ ), respectively, at Sault Ste. Marie (Fig. 1). Maps of isobases on the inferred Algonquin and Nipissing waterplanes were compiled, for example, in Leverett and Taylor (1915), Walcott (1972) and Lewis and Anderson (1989, Fig. 2). It is assumed that these shorelines have reached their present elevations through continuous but decelerating upward motion which can be described quantitatively as exponential decay (see Appendix). These isobases were used to estimate the post-Algonquin or post-Nipissing uplift parameters at each radiocarbon-dated site as required for input to the calculations of reconstructed (original) elevations (Table 1, Appendix).

The elevation of each dated site was adjusted to its value at the time of sediment deposition (Table 1), using the expressions in the Appendix. An adjusted elevation was also calculated and plotted for the ages defining the \pm error on each radiocarbon date. The curve joining these values in Fig. 10 is a part of the glacioisostatic uplift curve for each dated site. The Post Algonquin shore levels were also restored (Fig. 10) using this method. The full uplift history was also computed and plotted for the potential controlling outlets for Huron basin (Fig. 10), specifically the La Cloche saddle north of Manitoulin Island, Deane saddle between Manitoulin Island and Bruce Peninsula, and North Bay (Figs 1 and 2). The uplift history is also shown for head of 'Mackinac River' defining the elevation of the passage between Huron and Michigan basins (Fig. 1) (Lewis and Anderson, 1989).

In this method of reconstruction, all water-level -related data from all parts of the basin can be easily compared and evaluated. For example, all shallow-water sediments, shorelines and outlets which belong to a common lake level will cluster on the elevation vs. age diagram (Fig. 10) at a common altitude for a particular time. The basis for this method of reconstruction and that of the traditional shoreline diagram as used in Lewis and Anderson (1989; Figs 7a, b) is similar as both depend on the uplift isobases for correlating evidence of shorelines, shallow-water sediments, and outlets in different parts of 


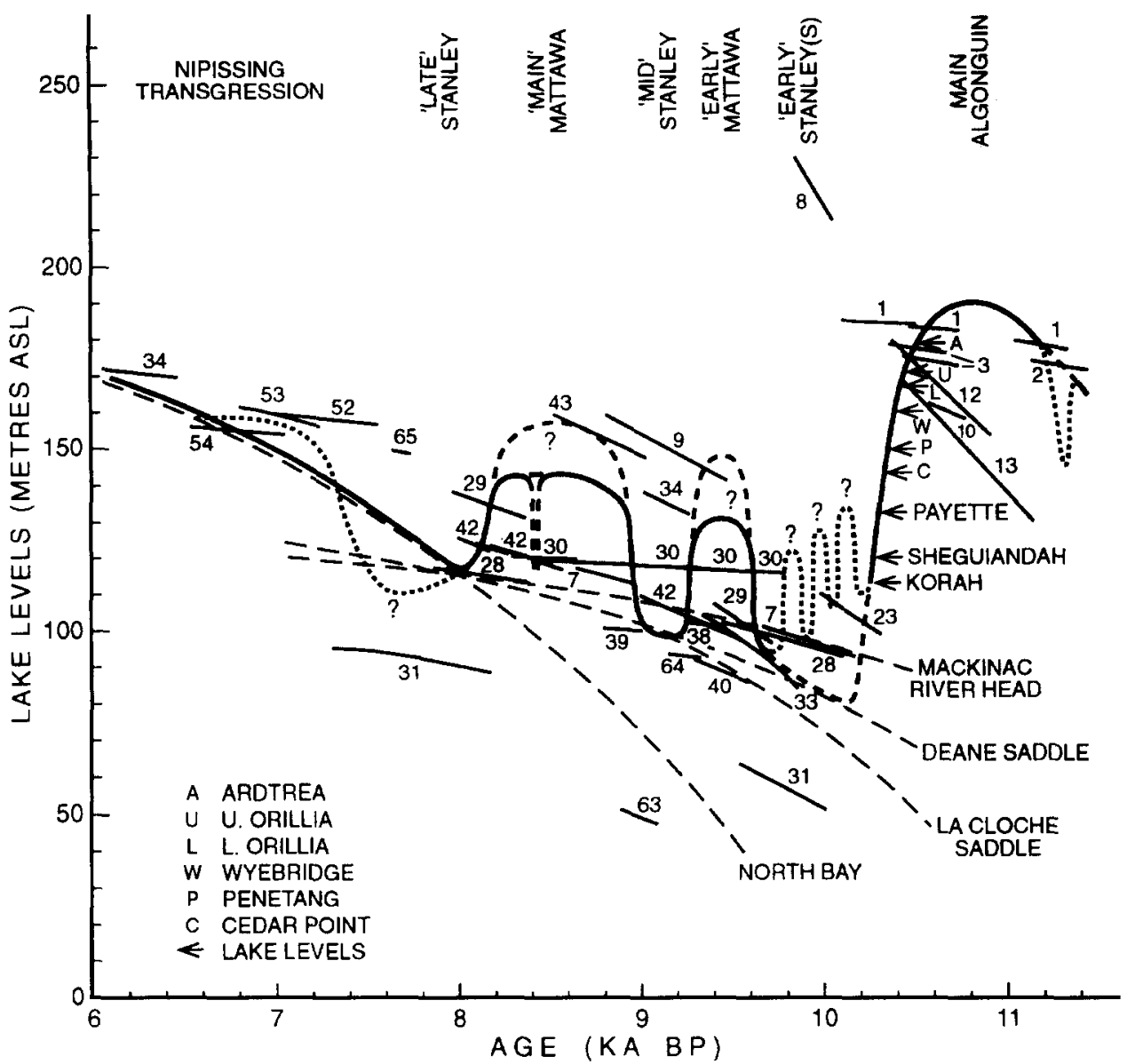

FIG. 10. Lake level history in the northern Huron basin between 11.5 and $6 \mathrm{ka}$ BP based on the integrated data from offshore sedimentary records, uplift history of key lake outlets, and from the shallow-water indicators of lake level (numbercoded to entries in Table 1 and locations in Fig. 2). Lake level data have been reconstructed to their original elevation at time of deposition. Solid line = interpreted lake level history; dashed line = alternate interpretations based on shallowwater data only; dotted line = alternate interpretation based on the offshore sedimentary record only. Named levels are the Post Algonquin shorelines. The Deane Saddle is the northern Lake Huron outlet to Georgian Bay (Fig. 2). The La Cloche Saddle is the outlet of North Channel to Georgian Bay (Fig. 2). Mackinac River head is the sill elevation between the Huron and Michigan basins (Fig. 2). North Bay is the sill elevation for the North Bay outlet (NB, Fig. 2) to the Mattawa and Ottawa River valleys.

the basin.

The accuracy of these reconstructions is thought to be about 2 to $5 \mathrm{~m}$; this is the range within which Nipissing shore elevations could be predicted from the exponential uplift parameters derived from the Algonquin shore data at points around the Huron basin. All adjustments are relative to Port Huron (PH, Fig. 2) at the southern end of Lake Huron.

\section{Lake Level History, Northern Lake Huron, 11-6 ka BP}

With the relevant water level indicator data adjusted to their original elevations (Appendix, Table 1), a lake level history for northern Lake Huron was drawn (Fig. 10). This history takes into account the significance of each datum (Table 1) and the indications of lake level change provided by the offshore sedimentary record (Rea et al., 1994b; Moore et al., 1994) as discussed below.

From 11.4 to $11 \mathrm{ka} \mathrm{BP}$, lake level in the Huron basin rose and occupied small basin sites 1 (Kincardine bog) and 2 (North Penetangore River, a former lagoon) under control of the uplifting Fenelon Falls outlet (FF, Fig. 2), as indicated by the solid and dashed line in Fig. 10. Two short periods of lake level decline at about 11.2 and 11.4 $\mathrm{ka} \mathrm{BP}$ are inferred from the presence of the offshore Dark Green and Dark Blue seismic reflectors (Moore et al., 1994; Rea et al., 1994b); one of these is indicated by the dotted curve in Fig. 10. From 11 to $10.5 \mathrm{ka} \mathrm{BP}$, the water level stood at the Main Algonquin phase (about $184 \mathrm{~m}$ ), which probably discharged through both Fenelon Falls and Port Huron outlets (Fig. 2, FF, PH respectively).

At $10.5 \mathrm{ka} \mathrm{BP}$, levels began to drop dramatically through the Post Algonquin phases (Ardtrea to Korah), abandoning the alluvial terrace at Eighteen Mile River (site 3) and the small basins of Upper Twin Lake (site 12), Lake Sixteen (site 10) and Prince Lake (site 13). The much lower Tehkummah Lake (site 23) was exposed at $10.2 \mathrm{ka}$ BP. The Post Algonquin series of lakes originated as ice retreated from outlets of successively lower elevation from the Lake Nipissing lowland to the Ottawa River valley (Harrison, 1972; Ford and Geddes, 1986). Although the Post Algonquin phases are traditionally understood as pauses in a general regression, it is possible some or all consist of a substantial drop and subse- 
quent rise to the indicated level. This might have occurred, for example, if high frequency oscillations characterized the ice margin retreat in the North Bay (Fig. 1) area, or if episodic outflows of enhanced glaciofluvial discharge from the upstream Marquette ice advance in the Superior basin passed through the Huron basin. Similarly, a fluctuating Marquette ice advance might have influenced overflow from Lake Agassiz into the Superior and Huron basins. Indeed, the presence of the Orange, Yellow 1 and 2 and Lower Light Green seismic reflectors in the offshore record (Figs 7 and 8 ) imply at least 4 lowstands separated by periods of higher lake level between 10.2 and $9.7 \mathrm{ka} \mathrm{BP}$ (dotted line, Fig. 10); it is possible that at least some of the shore features and sedimentary deposits in nearshore and alluvial environments of Post Algonquin age were formed by the high levels between these lowstands. Karrow (1986) listed one date on a Post Algonquin stream terrace at near $10 \mathrm{ka} B P$ in the southern Huron basin, but correlation to named lake levels is uncertain. The lowstands are interpreted to be progressively lower, as shown by the dotted curve in Fig. 10, because of the progressively greater truncation shown by their defining reflectors in seismic profiles (Moore et al., 1994). Overall, these lowstands appear to have been controlled at a higher level (by ice morainic dams?) than the bedrock sills on the Deane or La Cloche Saddles (Fig. 2) which are the obvious low points (outlets) over the basin rim for lakes in the northern Huron basin at this time (Fig. 10) (Lewis and Anderson, 1989). It is possible these lakes were still controlled by variable flows through the Aylen Channel or over a morainic dam across the Ottawa River valley near Deux Rivières, 33 $\mathrm{km}$ east of Mattawa (Fig. 1). During this transition, the lowstand in the Huron basin was low enough to expose the site of the older of the rooted stumps in the Straits of Mackinac (site 28). A correlative lowstand in Georgian Bay was low enough to expose the peat site at Hope Bay (site 7). In the absence of seismic reflector information, the lake level would have been interpreted differently, to have fallen directly through the Post Algonquin series of lakes toward the lowest outlet on La Cloche Saddle (Figs 2 and 10), but higher than the Wood Lake (33) and South Bay (42) sites which did not emerge until 9.6 and $9.3 \mathrm{ka}$ $\mathrm{BP}$, respectively, as shown by the dashed curve in Fig. 10. Even this lower lake level interpretation is above the local rock sills implying blockage by glacial debris, either on the Deane and La Cloche Saddles or in a downstream outlet, such as the Ottawa River valley as mentioned above.

At about 9.6-9.5 ka BP, the lake rose to the Early Lake Mattawa level to account for the deposition of clay over peat at Bruce Mines bog (site 29). This rise is also registered in the offshore record by the finer-grained period of deposition between the Light Green reflectors (Fig. 8). The driftwood in Flummerfelt Basin of Georgian Bay (older date at site 31) may have been eroded from nearby shoals which probably were forested islands during this lake rise. The maximum of this rise is poorly constrained. Possibly it rose to $150 \mathrm{~m}$ (Fig. 10) to deposit clay beneath peat at site 9 (Sheguiandah Bog). Alternatively, this site was exposed during the earlier Post Algonquin decline, after which organic deposition was slow to develop, as occurred at Greenbush Swamp at the Main Algonquin level (site 8, Fig. 10, Table 1). The rise is here interpreted to have inundated the Smoky Hollow Lake basin (site 34) to account for the inorganic sediment beneath gyttja dated at 9.1 ka BP (Table 1, Fig. 10). The lake level also inundated site 30 (Fig. 10, Table 1) in southwest Lake Huron, probably scouring the lakebed there prior to peat formation during the subsequent regression about 9.3-9.2 ka BP. Subaerial peat (site 40, Fig. 10, Table 1) at a relatively lower level in the adjacent Georgian Bay basin could have accumulated during either the Lower Light Green lowstand (latest of the Early Lake Stanleys, Fig. 10) or the Upper Light Green lowstand (Mid Lake Stanley, Fig. 10), given the relatively large error limits of its age (Table 1). The Early Mattawa highstand (Fig. 10) is also documented by inundation of the swamp environment at Hope Bay in Georgian Bay (site 7, Table 1) as shown by pollen and plant macrofossil analysis (Lewis and Anderson, 1989). Although the Early Lake Mattawa highstand stood about $25 \mathrm{~m}$ above the threshold into the Michigan basin (Mackinac River Head uplift curve, Fig. 10) and would have raised lake level there, the circulation and influence of Huron water in the Michigan basin at that time was not detected in a core from southern Lake Michigan (Colman et al., 1990, 1994a, b; Rea et al., 1994a).

The regression of lake level to the Mid Lake Stanley lowstand by about 9.3-9.2 ka BP is signified on Manitoulin Island (Fig. 2) by the onset of organic gyttja sedimentation in Smoky Hollow Lake (site 34, Fig. 10, Table 1) and the development of a shallow pond environment in South Bay (site 42; Lewis and Anderson, 1989). In southern Lake Huron, low lake level during the Mid Lake Stanley phase is also indicated by the accumulation of plant detritus and peat at sites 30,38 and 39 (Fig. 10, Table 1). The lake level descended to its relatively lowest position up to this time, to the northern Huron basin bedrock sills on the Deane and La Cloche saddles (Fig. 10). This is consistent with the character of the Upper Light Green seismic reflector which shows the greatest amount of truncation and erosion in the Huron basin. The Mid Stanley lake was isolated in the northern Huron basin; equivalent lakes would have existed at higher levels in the Michigan and southern Huron basins and at a lower level in the downstream Georgian Bay basin. Driftwood was deposited in northern (site 63) and western (site 64) Lake Huron in the later part of the Mid Lake Stanley phase, at the onset of transgressive lake levels to the Main Lake Mattawa highstand.

The transgression to the Main Lake Mattawa highstand, indicated by decreasing sediment grain size, bulk density and magnetic susceptibility in the offshore record, is signified by the termination of peat deposition at Hope Bay (site 7) and by shallow pond conditions at South Bay (site 42) in the shallow water record. Main Lake Mattawa rose at least $30 \mathrm{~m}$ above the Head of 
Mackinac River (Fig. 10), bringing waters in the Huron and Michigan basins to a common level. The influence of backflooding into the Michigan basin at this time has been recognized in a core from southern Lake Michigan by Colman et al. $(1990,1994 a$, b) (Rea et al., 1994a) as a change in the isotopic composition of ostracode shells. The preferred maximum for Main Lake Mattawa is about 145 m a.s.l., just below the Smoky Hollow Lake basin. An alternate interpretation would allow the Mattawa level to rise to $155-160 \mathrm{~m}$ a.s.1., to site 43 (Blind River Bog in a former lagoon) to account for the construction of a wave-built barrier. However, such a rise could have prematurely terminated the gyttja deposition in Smoky Hollow Lake which continued until 6.3 ka BP (site 34); it is possible the barrier was built earlier by Early Lake Mattawa or one of the Post Algonquin phases, and that organic deposition at site 43 was delayed. The ostracode record (discussed in a later section) implies that fluctuating levels typified the Main Lake Mattawa phase. A decline of this lake of approximately $25 \mathrm{~m}$ is implied by the presence of shallow pond plant detritus and shells in South Bay (site 42) at about $8.4 \mathrm{ka} \mathrm{BP}$ (Fig. 10, Table 1). This decline was likely short-lived as it apparently was not resolved in the offshore record.

Increasing sediment grain size at the Light Blue reflector in the offshore sedimentary sequence suggests decreasing water levels to the Late Lake Stanley lowstand about 7.8-7.5 ka BP (Figs 8 and 10). The shallow water record also shows evidence of lake level decline, by an in situ tree stump in the Straits of Mackinac (site 28), the deposition of plant detritus at Bruce Mines Bog (site 29), and the resumption of shallow pond conditions at South Bay (site 42) at about 8-8.1 ka BP (Table 1, Fig. 10).

From $8 \mathrm{ka} \mathrm{BP}$ onward, the North Bay outlet sill rose above the local outlets and took control of a common lake level in both Huron and Michigan basins, assuming a positive water budget for these lakes. This interpretation (solid line, Fig. 10) suggests that the Late Lake Stanley low phase began around $8 \mathrm{ka} \mathrm{BP}$ at the onset of the Nipissing transgression. The offshore record in this case is somewhat different, suggesting the lowest lake level occurred between 7.8 and $7.4 \mathrm{ka} \mathrm{BP}$ on the basis of coarser grain size in sediment cores. The reasons for this difference are not known, but might relate to uncertainty in the reconstruction of uplift of the North Bay outlet, as the shallow water indicators of water level are not in major disagreement with the lake level history inferred from the offshore record as shown by the dotted curve in Fig. 10. Only at site 54 should the dotted curve be $5 \mathrm{~m}$ lower to account for the growth of a tree near Beaver Island in northern Lake Michigan (Table 1, Figs 2 and $10)$.

Thus, a water level history has been constructed for northern Lake Huron which is consistent (within the uncertainty of radiocarbon dating, about 100 years) with both the offshore record and the shallow-water record of shore deposits and stratigraphic sections showing evidence of transgression or regression. This consistency provides considerable support for the interpretations of Moore et al. (1994) and Rea et al. (1994a, b) in which the offshore reflectors and associated zones of increased grain size represent lowstands of lakes in the northern Huron basin.

\section{Reconstruction Models}

A dynamic model of glacioisostatic recovery with northward migration of a collapsing forebulge for the Great Lakes region was published (Clark et al., 1994) while this review was being written. This geophysical model, an extension of one for the Michigan basin (Clark et al., 1990), suggests that Port Huron (PH, Fig. 2) was uplifted about $60 \mathrm{~m}$ over the $11-7 \mathrm{ka} \mathrm{BP}$ period. The predicted dynamic nature of the southern Lakes Huron and Michigan areas does not greatly affect the classic interpretation of the outlet chronology of the Great Lakes basin as reviewed here because our reconstructions are relative to Port Huron. For the 10 to $7 \mathrm{ka} \mathrm{BP}$ period at North Bay, for example, uplift predictions are reasonably similar to the present results - from 30 to $170 \mathrm{~m}$ a.s.l. for the Clark et al. model (E2) compared with 13 to 145 $\mathrm{m}$ a.s.l. for the empirical model used here.

However, dissatisfaction with the long-held view (Goldthwait, 1908; Leverett and Taylor, 1915) that the earth's crust under the southern Great Lakes has been stable since at least Main Lake Algonquin, has been expressed by Calkin and Feenstra (1985) and especially by Larsen (1987) among others. Lewis and Anderson (1992) noted that the Port Huron outlet (PH, Fig. 2) must have been operating from 12 to $10.5 \mathrm{ka} \mathrm{BP}$ to account for thick glaciolacustrine sediments in Lake Erie containing ostracodes with relatively light $\delta^{18} \mathrm{O}$ values ( -9 to -12 per mil) thought to be influenced by isotopically light glacial meltwater from the Huron basin (Fritz et al., 1975). Yet, the reconstructions of both Kaszycki (1985) and Larsen (1987) do not allow this drainage because they project the northern Algonquin shorelines southward below the Port Huron outlet. The apparent conflict would be resolved if the Port Huron area were depressed in the Algonquin phase relative to its present elevation. It is clear that careful reconsideration of the geological data and inferences of former shorelines and runoff drainage should be undertaken in light of the Clark et al. (1994) model findings.

\section{Seismic Reflectors and Hough's Low Level Lake Stanley Stage}

One of our seismic profiles and core $37 \mathrm{P}$ (Fig. 2) (Moore et al., 1994; Rea et al., 1994b) were obtained in the same location in northwestern Lake Huron as were the cores Hough (1962) used to define low level Lake Stanley; our reflectors and grain size profiles were compared directly with Hough's core logs (Fig. 2 in Hough, 1962). The Stanley low-water unconformable zone described earlier matches the coarse-grained zone associated with the Light Blue reflector in our data, further confirming the interpretation of the seismic reflectors in the 
Huron basin during the Mattawa phase as lake-level lowstands. This connection shows also that the Stanley low stage which Hough defined is actually the youngest (7.8-7.5 ka BP) of several lowstands since the Main Lake Algonquin (Fig. 10). The Upper Light Green coarse zone in core 37P, below the Light Blue event, matches a similar silty zone in Hough's cores, but he interpreted the lower coarser zones as "late-glacial events, such as outwash deposition when the margin ... of ice was located on the Upper Peninsula of Michigan", rather than as earlier low-water lake events. This was a logical deduction at the time, but should now be rejected. It is now clear that the previous concept of a single early low-level Lake Stanley marking the onset of a long period of slowly rising transgressive lake levels under the influence of the North Bay outlet sill (NB, Fig. 2) is outmoded. Instead, as depicted in Fig. 10, a succession of alternating lowlevel 'Stanley' lakes and relative highstands occurred in the Huron basin after Main Lake Algonquin, spanning approximately the period $10.5-7.5 \mathrm{ka} \mathrm{BP}$. Only at the end and following this period, did the sill of the North Bay outlet (NB, Fig. 2) become a controlling threshold for lake levels in the Huron or Michigan basins (Lewis and Anderson, 1989).

At least four lowstands and intervening highstands are defined in the Huron basin between the end of the Main Algonquin phase at $10.5 \mathrm{ka} \mathrm{BP}$ and the lake rise at $9.6 \mathrm{ka}$ BP. The detailed causes of these fluctuations will only become clear with further study. The highstands could account for some or many of the Post Algonquin shorelines, and the fluctuations could be due to variations in constrictions between the receding ice and the highlands south of North Bay and Mattawa (Fig. 1), meltwater releases from the Marquette advance in Superior basin, or the presence of morainic dams. Until these are better understood, we suggest the whole period of widely fluctuating lake levels between the Main Algonquin phase and the Nipissing transgression be informally referred to as the Mattawa-Stanley phase.

\section{Molluscan and Ostracode Records}

\section{Molluscan fauna in shallow-water and terrestrial sediments}

Miller et al. (1985) found distinctive fossil assemblages among 112 taxa of aquatic and terrestrial molluscan taxa from 52 estuarine and fluvial sites around Lake Huron and the southern Georgian Bay. The assemblages are from sediments deposited during the Algonquin, Algonquin-Nipissing transition and Nipissing lake phases. Sixteen of 55 taxa related to the Main Algonquin water level are unique, 27 of 61 taxa first appeared in the transitional phase (10-6 ka BP) of which 8 are unique and 25 of 72 are unique to the Nipissing phase.

The Algonquin assemblages indicate that even shallow waters in southern Georgian Bay were cold, with mean temperatures no higher than $3.6^{\circ} \mathrm{C}$. This is consistent with the Main Lake Algonquin setting, a large lake with an ice margin, and possibly a large inflow from the
Agassiz basin which would enhance the circulation and advection of cold surface water through the lake. The new appearances in the transitional assemblages are dominantly terrestrial gastropods and aquatic taxa characteristic of small ponds, lakes and streams. These changes are consistent with the reduced but fluctuating levels of the Mattawa-Stanley phase and subsequent Nipissing transgression compared to the prolonged higher levels of the preceding Main Lake Algonquin and succeeding Nipissing Great Lakes. Lower levels and widespread exposure of the southern Lake Huron lake bottom would facilitate the migration of terrestrial forms, while disuse of the Port Huron outlet and high flows of cold meltwater drainage down the Ottawa River valley would inhibit the migration of new aquatic taxa into the Huron basin. These constraints were removed by Nipissing time so that aquatic fauna were able to migrate into the Huron basin through the North Bay and southern outlets.

\section{Ostracode record of offshore sediments}

Ostracode assemblages in the offshore sediments of Lake Michigan have provided useful information regarding changes in the limnology of that lake (Colman et al., 1990; Forrester et al., 1994). Ostracode assemblages for the master core 37 (Fig. 2) in northwestern Lake Huron have been identified and 7 biostratigraphic zones recognized (Fig. 11) (Smith et al., submitted). The relative ages of the zone boundaries were estimated on the basis of their depth in the core and the master $\mathrm{AMS}^{14} \mathrm{C}$-calibrated age model for the same core (Rea et al., 1994b). Zone 1 at the base of the core contains a sparse assemblage of Candona rawsoni juveniles with a few juveniles of Candona subtriangulata and Limnocythere friabilis, suggesting the shore zone was frequently near the core site. This $9.8-9.6 \mathrm{ka} \mathrm{BP}$ period is the latest of the Early Lake Stanley lowstands (Fig. 10).

Briefly, in zone 2, C. subtriangulata increases in abundance for an estimated 30 years, signifying cold, very dilute meltwater (about $4^{\circ} \mathrm{C}$ with $<100 \mathrm{mg} / 1$ total dissolved solids (TDS)). This zone is associated with the onset of water level rise to the Early Lake Mattawa highstand (Fig. 10). It is possible that these waters were influenced by eastward drainage from the Post-Duluth glacial lakes in the western Superior basin (Farrand and Drexler, 1985).

From about 9.6 to $9.3 \mathrm{ka} \mathrm{BP}$ in zone $3, C$. rawsoni and L. friabilis dominate and $C$. subtriangulata declines, suggesting a mixture of taxa from nearshore and deeper areas in waters containing more TDS (> $100 \mathrm{mg} / \mathrm{l}$ ). These changes suggest the lake environment was characterized by fluctuations in level and a shift in inflow from glacial meltwater to terrestrial runoff sources. Zones 2 and 3 possibly reflect higher but fluctuating lake levels (Early Lake Mattawa) associated with initial drawdowns of glacial lake Agassiz through its eastern (Nipigon) outlets (Clayton, 1983; Teller and Thorleifson, 1983, 1987; Farrand and Drexler, 1985).

In zone $4, C$. subtriangulata increases at the expense of the other taxa, L. friabilis and C. rawsoni, from about 


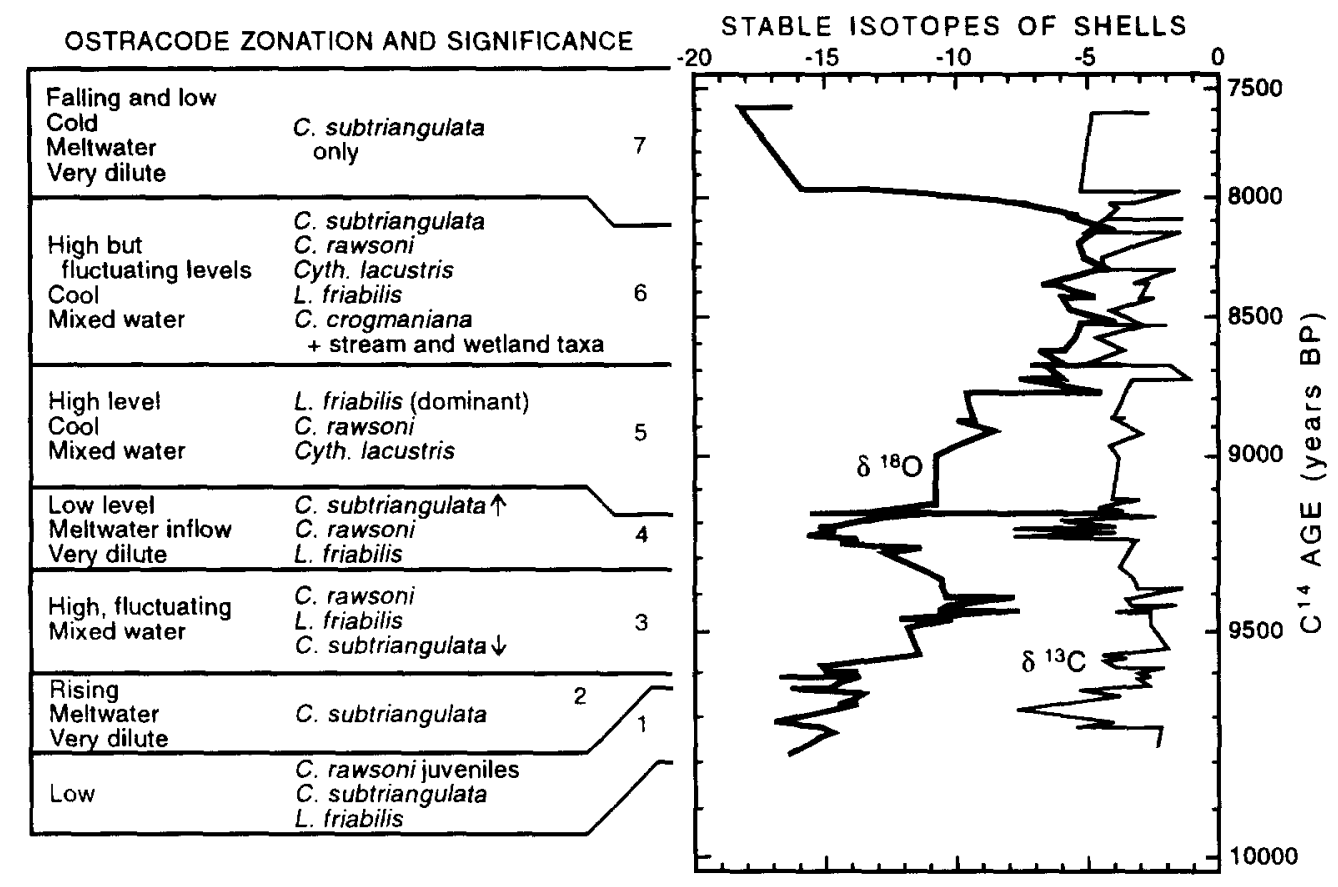

FIG. 11. Stable isotopes ( $\mathrm{O}$ and $\mathrm{C}$ ) and ostracode zones in northwestern Lake Huron for core 37P (69 $\mathrm{m}$ water depth) (Fig. 2) (after Dettman et al., in press; Smith et al., submitted). The isotopic measurements are mostly on $C$. subtriangulata or, in its absence, $C$. rawsoni; measurements are relative to the PDB standard. The ostracode genus abbreviations are: $C$. = Candona; Cyth. $=$ Cytherissa $L=$ Limnocythere. The upward arrow indicates that the $C$. subtriangulata component of the assemblage is increasing up core; the downward arrow indicates that it is decreasing. Very dilute $=<100 \mathrm{mg} / 1 \mathrm{total}$ dissolved solids.

9.3-9.1 ka BP. These changes indicate a return to cold, very dilute $(<100 \mathrm{mg} / \mathrm{l})$ conditions with lake inflow probably dominated by a glacial meltwater source. This zone is mainly associated with sediments of the Mid Lake Stanley lowstand (Fig. 10).

Zone 5 persisted for a relatively longer period (9.1-8.7 ka BP), and is characterized by the disappearance of $C$. subtriangulata, the dominance of $L$. friabilis, and the presence of $C$. rawsoni and Cytherissa lacustris. The assemblages of this zone imply a decrease in the inflow of glacial meltwater or an increase in terrestrial runoff containing more TDS (>100 mg/l). The zone is mostly associated with finer-grained sediment of the Main Lake Mattawa highstand.

Zone 6, deposited from 8.7 to $8.1 \mathrm{ka} \mathrm{BP}$, is marked by a wide range of ostracode species, likely transported from different habitats. The zone includes the four species in previous zones plus Candona crogmaniana with other stream and wetland taxa. These, together with a fine sediment matrix suggest high but fluctuating lake levels, supported by precipitation runoff, through the remainder of the Main Lake Mattawa highstand (Fig. 10). The absence of $C$. subtriangulata in this fauna suggests the presence of some dissolved solids (>100 mg/l) in the lake water.

The transition from zone 6 to 7 is marked by a change to $C$. subtriangulata; this monospecific interval suggests an environment of cold, very dilute $(<100 \mathrm{mg} / \mathrm{l})$ meltwater. This zone is coeval with the Late Lake Stanley lowstand which persisted from about 8 to $7.5 \mathrm{ka} \mathrm{BP}$. This lowstand terminates the Mattawa-Stanley phase of high but variable lake levels and marks the onset of the Nipissing transgression in the Huron basin.

\section{$\delta^{18} \mathrm{O}$ and $\delta^{13} \mathrm{C}$ Stable Isotope Records}

The $\delta^{18} \mathrm{O}$ history of waters in Lake Huron from 9.8 to $7.4 \mathrm{ka} \mathrm{BP}$ is based on $\delta^{18} \mathrm{O}$ measurements of the ostracodes and bivalves in core 37P (Figs 2 and 11) (Dettman et al., in press). These show light values of -14 to -17 per mil during the 9.8-9.6 ka BP period of ostracode zones 1 and 2; at this time lake levels were low during the Early Lake Stanley lowstand, associated with coarsergrained offshore sediment and the Lower Light Green reflector. From 9.6 to $9.3 \mathrm{ka} \mathrm{BP}$ the $\delta^{18} \mathrm{O}$ values became heavier, -11 and briefly to -8 per mil. These values occurred during ostracode zone 3 when lake levels were high and fluctuating during the Early Lake Mattawa highstand. From 9.3 to $9.1 \mathrm{ka} B P$, the $\delta^{18} \mathrm{O}$ values again became light, between -13 and -16 per mil, during ostracode zone 4 and the Mid Lake Stanley lowstand. This episode is associated with the Upper Light Green reflector. As can be seen in Fig. 11, from about 9.1 to $8.8 \mathrm{ka}$ $\mathrm{BP}$, the $\delta^{18} \mathrm{O}$ values slowly became heavier and ranged between -11 and -10 per mil during ostracode zone 5 . These values became even heavier, from -7 to -5 per mil (modern values are about -4 per mil), during the following ostracode zone 6 from about 8.7 to $8.1 \mathrm{ka} \mathrm{BP}$. Both these zones were deposited during high but fluctuating 
levels of the Main Lake Mattawa highstand. After $8.1 \mathrm{ka}$ $\mathrm{BP}$ to the end of the record at $7.4 \mathrm{ka} \mathrm{BP}$, the $\delta^{18} \mathrm{O}$ ratios descended to their lightest values, between -14 and -18 per mil. This descent occurred during the Late Lake Stanley lowstand and the deposition of coarser-grained sediment which gives rise to the Light Blue reflector.

As shown in Fig. 11, the $\delta^{13} \mathrm{C}$ isotope ratios (PDB) in the ostracodes and bivalves from core $37 \mathrm{P}$ (Fig. 2) are much more stable and similar to modern values, only 2 to 4 per mil lighter than at present (Dettman et al., in press; Rea et al., 1994a, b). These values lightened to -7 to -8 per mil only at times of the two earliest light $\delta^{18} \mathrm{O}$ excursions, about 9.7 and $9.2 \mathrm{ka} \mathrm{BP}$. The interpretation of these variations is uncertain, as they could be caused by variable changes in dissolved inorganic carbon in the lake water or changes in food sources for the organisms (Dettman et al., in press).

The large $\delta^{18} \mathrm{O}$ variations exceed variations that can be attributed to seasonal lacustrine temperature changes or even to a slightly more negative precipitation in the early Holocene. The unusually light $\delta^{18} \mathrm{O}$ values could only have arisen through extremely low temperature precipitation as would have occurred at high elevation on the Laurentide Ice Sheet, and thus the negative $\delta^{18} \mathrm{O}$ excursions in the ostracodes and bivalves must indicate the dominant presence of glacial meltwater in these lakes (Dettman et al., in press; Smith et al., submitted; Coleman et al., 1990). It is clear from Fig. 11 that meltwater dominated this site (core 37P, Fig. 2) in northwestern Lake Huron during the Lake Stanley lowstands when $\delta^{18} \mathrm{O}$ was lighter than -13 per mil. Conversely, the intervening Lake Mattawa highstands were not obviously influenced by meltwater, and their isotopic composition suggests the dominant presence of terrestrial precipitation and runoff.

The $\delta^{18} \mathrm{O}$ profiles at 4 sites throughout Lake Huron and Georgian Bay (37P, 22P, 3P and M17; Figs 2 and 12) define the isotopic composition of ostracodes in the Huron basin between 12 and $7.5 \mathrm{ka} \mathrm{BP}$ (Rea et al., 1994a; Dettman et al., in press). The record from 22P in northern Lake Huron is nearly identical with that of 37P in northwestern Lake Huron, supporting the occurrence of light $\delta^{18} \mathrm{O}$ values and meltwater dominance for the Early and Mid Lake Stanley lowstands. Minor differences in these records are likely due to small hiatuses or changes in sedimentation rates between the 2 locations (Dettman et al., in press).

The older record present at site M17 in southwestern Lake Huron (Fig. 2) is, by comparison, only moderately light. This could reflect meltwater from a more southerly margin of the Laurentide Ice Sheet (Figs 5c, d) than the margin supplying water to the later, early Holocene lowstands (Figs 6d, e). Precipitation on the more northerly, and higher part of the Laurentide Ice Sheet would likely have been at a lower temperature, and would, therefore, have subsequently produced meltwater with a more negative $\delta^{18} \mathrm{O}$ composition. The negative excursion after $11 \mathrm{ka}$ BP at site M17, and a similar excursion in Lake Erie is attributed to enhanced meltwater drainage from glacial Lake Agassiz (Rea et al., 1994a; Lewis and Anderson, 1992). A negative excursion of $\delta^{18} \mathrm{O}$ in bivalves and ostracodes in cores from southern Lake Michigan at this time is also attributed to an influx of meltwater from glacial Lake Agassiz (Colman et al., 1994b).

The record from $3 \mathrm{P}$ suggests that after $10.2 \mathrm{ka} B P$ the Huron basin was influenced by lighter $\delta^{18} \mathrm{O}$ meltwater, and that lighter water continued to influence Georgian Bay while water in the northern Huron basin became heavier during the Early Lake Mattawa highstand after $9.5 \mathrm{ka} \mathrm{BP}$. This suggests a reduction in hydraulic connection between the basins (Dettman et al., in press; Rea et al., 1994a) while meltwater flowed from the Superior basin directly to the Georgian Bay basin and the Ottawa River valley via the North Channel, largely bypassing the

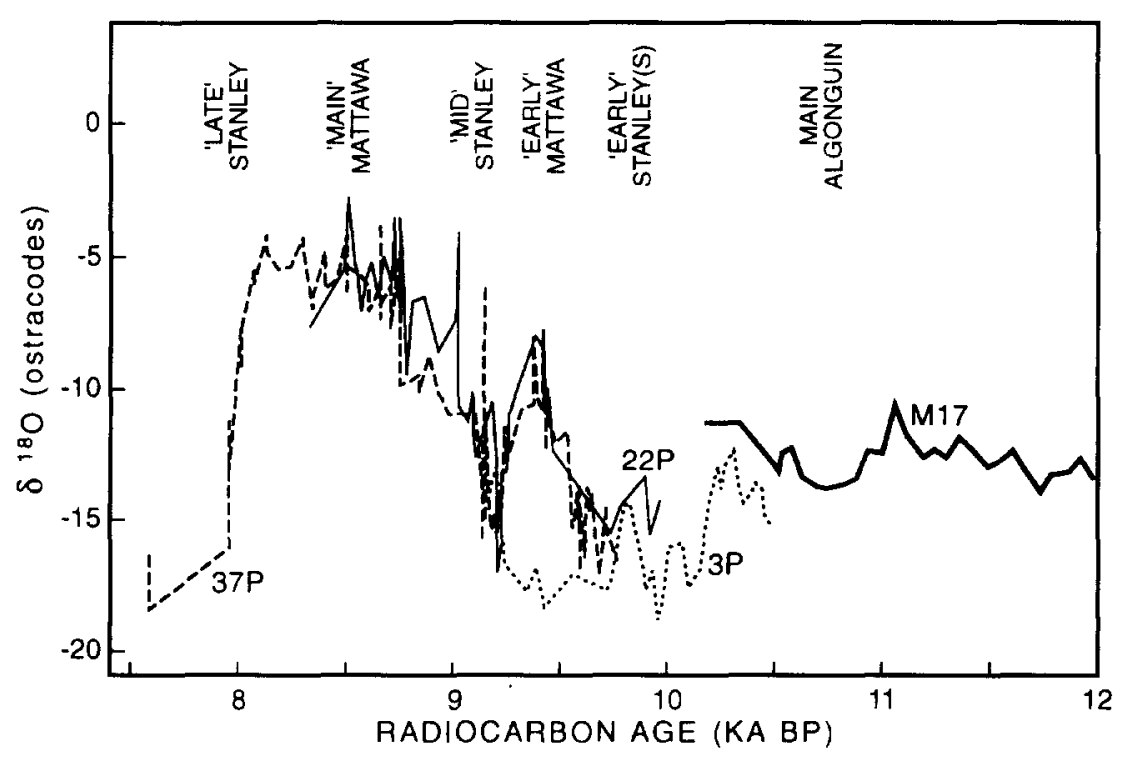

FIG. 12. $\delta^{18} \mathrm{O}$ isotope records (relative to PDB) from benthic ostracodes in core 37P (northwestern Lake Huron), 22P (northern Lake Huron), M17 (southwestern Lake Huron) and 3P (Georgian Bay) (after Rea et al. (in press a)). See Fig. 2 for core locations. Lake names are given for phases of the Huron-basin lake level history. 
northern Lake Huron basin (Figs 2, 6d). This is quite likely as the North Channel exit to Georgian Bay (La Cloche saddle, Figs 2, 10) was lower than the connections from the northern Huron basin to Georgian Bay (Deane Saddle, Figs 2, 10) or to North Channel west of Manitoulin Island (Fig. 2). Alternatively, meltwater from Lake Barlow-Ojibway could have backflooded into Georgian Bay without circulating into the Huron basin as a result of hydraulic damming in the Ottawa River valley outlet during periods of high flow (Figs 6d, e) (Lewis and Anderson, 1989).

After the lowstand at $9.2 \mathrm{ka} \mathrm{BP}$, lake waters from the Main Lake Mattawa highstand in the Huron basin circulated into the Michigan basin where a $\delta^{18} \mathrm{O}$ negative excursion is registered in southern Lake Michigan (Colman et al., 1990, 1994a, b). This light excursion declines in sympathy with the increasingly heavy isotopic composition registered in northwestern Lake Huron ostracodes after $8.7 \mathrm{ka} \mathrm{BP}(37 \mathrm{P}$, Figs 11,12$)$. However, this hydraulic connection ended after $8.1 \mathrm{ka} \mathrm{BP}$ when the Huron basin lake levels descended to the Late Lake Stanley lowstand with its extremely negative ostracode $\delta^{18} \mathrm{O}$ values (37P, Figs 11,12 ), as no similar excursions were detected in the southern Lake Michigan isotopic record (Colman et al., 1990, 1994a, b). Only after $7.5 \mathrm{ka}$ BP did the Michigan and Huron basin lakes again become confluent, rising together throughout the Nipissing transgression under the influence of the North Bay outlet sill (Fig. 10).

\section{Origin of Inflows, 9.6-8 $\mathrm{ka} \mathrm{BP}$}

The origin of the variations in water composition in the northern Huron basin as reflected in the fluctuating record of ostracode assemblages and their isotopic composition is perplexing (Rea et al., 1994a). The expectation was that a signature for cold meltwater would correlate to lake highstands caused by large inflows from glacial Lake Agassiz (Lewis and Anderson, 1989). Instead, highstands are characterized by heavy $\delta^{18} \mathrm{O}$ and an ostracode assemblage favoring high total dissolved solids (TDS), whereas lowstands are represented by light $\delta^{18} \mathrm{O}$ (meltwater) and a monospecific Candona subtrianguluta ostracode fauna that favors low TDS (Rea et al., 1994a, b; Smith et al., submitted; Dettman et al., in press).

The simplest explanation is to assume a more or less constant inflow of meltwater and precipitation runoff. Highstands will have greater lake volume and longer residence times as well as larger surface area and more exposure to evaporation, thereby favoring the accumulation of heavier $\delta^{18} \mathrm{O}$ water. The lowstands, on the other hand, were lakes of reduced area and volume; these would be less exposed to evaporation effects and would provide less residence time for local precipitation runoff to dominate the hydrology (Rea et al., 1994a). Mechanisms which increase the inflow of meltwater during times of low lake level have also been considered. Dettman et al. (in press) proposed oscillatory ice margin recession at lake outlets with enhanced meltwater output, with very negative $\delta^{18} \mathrm{O}$ values, during the retreat phases when lake levels would be lower. This proposal could only apply to lake level fluctuations prior to $10 \mathrm{ka} \mathrm{BP}$; after this date, the ice margin was retreating rapidly up the Ottawa River valley past Témiscaming (Figs 1, 6d) and could not affect outlets of the Great Lakes in the North Bay area (Figs 1, 2).

Another approach is to consider an increase in precipitation runoff, characterized by much more positive $\delta^{18} \mathrm{O}$ values during the highstands, especially after $9.6 \mathrm{ka} \mathrm{BP}$. Smith et al. (submitted) and Dettman et al. (in press) noted that the ostracode fauna of the higher Early and Main Mattawa lakes excludes Candona subtriangulata, a species which is restricted to very dilute water $(<100$ mg/l TDS). They point out that this could imply that precipitation runoff increased relative to meltwater inflow and carried enough TDS to discourage Candona subtriangulata during the Mattawa highstands. In this scenario, it is only during the lowstands that the higher TDS precipitation runoff declines and the low TDS meltwater inflow becomes dominant in the northern Huron basin. This is plausible because the higher inflows of precipitation runoff during the highstands could account for the higher lake levels through hydraulic damming at constrictions in narrow outlet valleys (Lewis and Anderson, 1989). We will pursue this idea by seeking connections with events in the Agassiz, Superior and Nipigon basins which served as the likely source and pathway for inflows to the northern Huron basin after $9.6 \mathrm{ka} \mathrm{BP}$.

\section{Comparison with the varve record of Superior basin}

A 1500 to 1600 year sequence of calcareous rhythmite sedimentation is known from cores collected in Lake Superior. An upward color transition from red to grey occurs in the lower part (first 250-300 years) of the Superior varve record, reflecting the northward retreat of the glacier margin across red then grey lithologies (Farrand, 1969a, b; Dell, 1972, 1975; Teller and Mahnic, 1988). The varves are highly calcareous except for a thin $(10-40 \mathrm{~cm})$ unit of non-calcareous, non-varved clay near the top of the laminated sequence (Dell, 1974; Lineback et al., 1979). North of Lake Superior, Thorleifson and Kristjansson (1993) also inferred a 1600 year record of varve thicknesses near Dorion (Fig. 13), based on the work of Teller and Mahnic (1988) who examined sections and boreholes in the lowlands and channels between the Nipigon and Superior basins. These records span the period of Laurentide ice recession from the Superior basin, following the Marquette advance, to the diversion of meltwater and entrained sediment from the northern drainage divide between the western Great Lakes and Hudson Bay. Retreat of ice from the Superior basin and its north shore is estimated at $9.6 \mathrm{ka} \mathrm{BP}$, just prior to opening of the eastern outlets of Lake Agassiz. The demise of varve sedimentation in northern Lake Superior is estimated at about $8 \mathrm{ka} \mathrm{BP}$ (Mothersill, 1988). These dates, 9.6-8.0 ka BP, are assumed to bracket the varve record (Fig. 13) (Thorleifson and Kristjansson, 

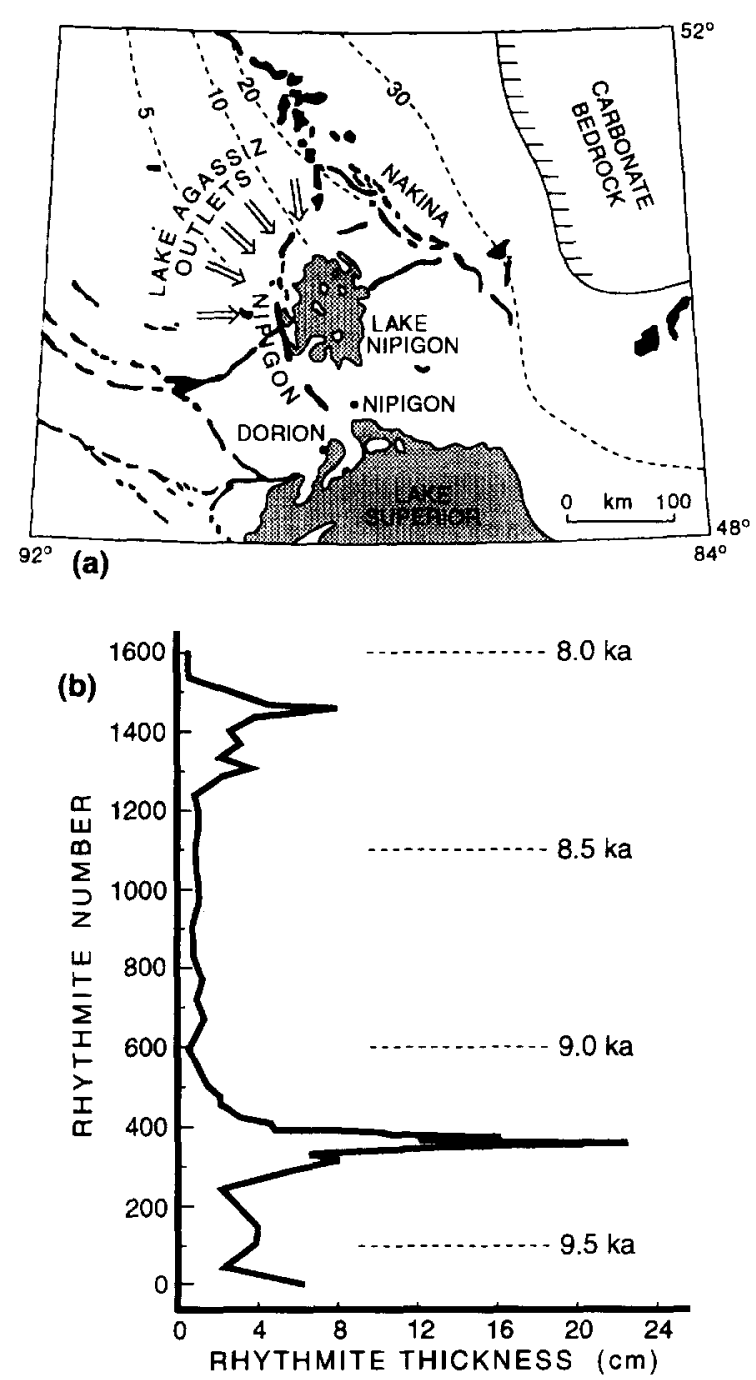

FIG. 13. (a) Map of the Lake Nipigon area north of Lake Superior showing the distribution of moraines, outlets of Lake Agassiz, proximity of carbonate bedrock of Hudson Bay lowlands, and isopleths of percent carbonate in the local till matrix (after Thorleifson and Kristjansson, 1993; Dredge and Cowan, 1989). (b) A 1600 year record of rhythmite thickness from the Dorion area, north shore of Lake Superior, based on Teller and Mahnic (1988) (after Thorleifson and Kristjansson, 1993).

\section{3).}

The Dorion varve record (Fig. 13) shows a decreasing accumulation rate from about $6 \mathrm{~cm} /$ year at $9.6 \mathrm{ka} \mathrm{BP}$ to about $1 \mathrm{~cm} /$ year at $9 \mathrm{ka} \mathrm{BP}$, reflecting northward retreat of the ice margin and a steady decline in glaciofluvial sediment reaching the Dorion area. Accumulation continued at about $1 \mathrm{~cm} /$ year until $8 \mathrm{ka} \mathrm{BP}$. This record is punctuated by two episodes of greatly increased deposition at 9.35-9.1 ka BP and 8.35-8.05 ka BP, explained by local ice stream advances to the Nipigon and Nakina moraines, respectively, which are located just west and north of the Nipigon basin (Fig. 13) (Thorleifson and Kristjansson, 1993). The Nipigon advance would have filled the Nipigon basin with ice and dammed the nearby outlets from Lake Agassiz (Fig. 13). The resulting reduction in inflow to the Superior and Huron basins is reflected by the lowered lake level of the Huron basin during the Mid
Lake Stanley lowstand (Fig. 10). Retreat of this ice after 9.1 ka BP would have restored the Agassiz inflow to the Superior basin; this event is reflected in the Huron basin by the onset of lake level rise to the Main Lake Mattawa.

The timing of isotope variations in the Huron basin (Figs 11, 12) can be interpreted to reflect the fluctuations in inflow implied by ice movements in the Lake Nipigon area. The recession at $9.5 \mathrm{ka} \mathrm{BP}$ which opened the Agassiz outlets is accompanied by increasing $\delta^{18} \mathrm{O}$ values in the Huron basin ostracode record (Fig. 11). The dramatic decrease in $\delta^{18} \mathrm{O}$ values at about $9.2 \mathrm{ka}$ parallels the closure of these outlets and correlates with increase delivery of meltwater by the advance of an ice stream to the Nipigon moraine shown by thickening of the rhythmites (Fig. 13). The lightening of $\delta^{13} \mathrm{C}$ values at the same time might reflect mobilization of terrestrial organic materials by the same advance. The subsequent trends toward heavier values in both $\mathrm{C}$ and $\mathrm{O}$ isotopic composition after 9.2 ka correlate with the retreat of Nipigon ice and resumption of inflow from glacial Lake Agassiz.

Thus, the switching of glacial Lake Agassiz outflow by ice stream advances and retreats in the Nipigon basin correlates with the major lake level variations of the northern Huron basin between 9.6 and $9 \mathrm{ka} \mathrm{BP}$; when Agassiz discharge entered the Superior basin, lake levels in the Huron basin were raised, and when the Agassiz discharge was diverted or impeded, lake levels were lowered. The switching also correlates with the timing of major changes in isotopic composition. However, this scenario presents a conundrum, which will be discussed later: how can a glacial lake, Lake Agassiz, discharge water with the isotopic composition of precipitation runoff, as implied by the ostracode $\delta^{18} \mathrm{O}$ values in the downstream Huron basin?

The younger period of enhanced varve deposition at Dorion (upper set of thicker rhythmites, Fig. 13) is associated with glaciofluvial (meltwater) activity during an advance of ice to the Nakina Moraine (Fig. 13) (Thorleifson and Kristjansson, 1993). This advance formed Lake Nakina which flowed over the Great Lakes-Hudson Bay drainage divide to the Nipigon and Superior basins (Fig. 1). A short period of ice recession and outwash diversion north of the drainage divide occurred before the readvance of ice to the Nakina Moraine (Prest, 1970; Dyke and Prest, 1987; Barnett, 1992; Thorleifson and Kristjansson, 1993) that resulted in the onset of thicker rhythmites at about $8.3 \mathrm{ka} \mathrm{BP}$ (Fig. 13). We speculate that this diversion of meltwater inflow correlates with a short-lived reduction in the Huron basin lake level at about 8.4-8.3 ka BP (Fig. 10). The Agassiz inflow was not impeded and would have continued unabated throughout the pre-Nakina meltwater drainage diversion.

The sensitivity of the Dorion varve record to glaciofluvial activity shows that inflows from north of the Nipigon basin are a probable source for meltwater (likely with extremely negative $\delta^{18} \mathrm{O}$ composition), being closest to the margin of the Laurentide ice (Fig. 6e) (Lewis and Anderson, 1989, Figs 8d, e). An alternate 
source for meltwater could be discharge from glacial Lake Ojibway which backflooded into the northern Huron basin through the Nipissing-Georgian Bay lowland (Fig. 6e). We speculate that the high discharge Agassiz inflows $\left(25,000-50,000 \mathrm{~m}^{3} \mathrm{sec}^{-1}\right.$ equilibrium flow and $100,000 \mathrm{~m}^{3} \mathrm{sec}^{-1}$ flood discharge, Teller and Thorleifson, 1983, 1987; Teller, 1990) would have greatly diluted this meltwater while raising lake levels in the Huron basin. These, we postulate, would be the Mattawa highstand conditions. When the high discharge Agassiz inflows were not operating, lake levels would have been reduced and the meltwater inflow would continue undiluted. These, we postulate, would be the Stanley lowstand conditions.

\section{Composition of Lake Agassiz outflows}

So far this scenario explains the lowstands with light $\delta^{18} \mathrm{O}$ meltwater and low TDS Candona subtriangulata fauna. However, the real problem is the difficulty in understanding how the $\delta^{18} \mathrm{O}$ composition of the glacial Lake Agassiz outflow water could be heavy, in the range of the isotopic composition of precipitation runoff, and that it could be the source of TDS implied by the highstand fauna of the northern Huron basin. The possibility of this being the case is enhanced for at least 5 reasons. First, the meltwater source (ice margin) was increasingly distant from the outlets, particularly in the later phases of Lake Agassiz (e.g. Fig. 6e). Second, the lake was likely stratified in its southern regions during summers, with cold, denser meltwater seeking a position beneath warmer, lighter runoff from exposed land areas. Third, the runoff would likely have acquired TDS from the exposed land areas of western Canada. Fourth, evaporation would tend to make the surface water heavier with respect to $\delta^{18} \mathrm{O}$ composition. Fifth, only surface water from the southeastern part of the lake (overflow through the eastern outlet channels (Teller and Thorleifson, 1983) was discharged to the Great Lakes. This scenario is supported by Teller's (1990) analysis of Laurentide ice recession which suggests that the major part $(60-75 \%)$ of the total runoff in the Lake Agassiz watershed was precipitation runoff between 10 and $8 \mathrm{ka}$ BP. The analysis also shows the availability of large volumes of runoff throughout the early Holocene, which is consistent with the proposed scenario of higher lake levels in the downstream Great Lakes basins during periods of large Agassiz inflow.

Further support for the scenario is provided by a reconnaissance investigation of ostracodes and bivalves from Lake Agassiz sediments beneath the present Lake Manitoba, about $150 \mathrm{~km}$ northwest of Winnipeg (Fig. 1). This study provides critical insight into the likely chemical and isotopic composition of Lake Agassiz water (Last et al., in press). When this site was inundated by the deep ice-marginal Lockhart phase of Lake Agassiz prior to 11 ka BP, it supported a Candona subtriangulata fauna with a strongly negative $\delta^{18} \mathrm{O}$ isotopic composition, -15.3 to -16.4 per mil. The presence of the $C$. subtriangulata fauna implies that this lake water was cold (about $4^{\circ} \mathrm{C}$ ) and dilute ( $<100 \mathrm{mg} / 1 \mathrm{TDS})$ with little seasonal variability (Last et al., 1994). Water of this composition would be sufficient to account for the downstream negative $\delta^{18} \mathrm{O}$ excursions attributed to Lake Agassiz inflows at about 11 ka BP in the Huron (Rea et al., 1994a), Michigan (Colman et al., 1990, 1994a, b) and Erie (Lewis and Anderson, 1992) basins.

After Lake Agassiz drained to the Moorhead lowwater phase after $11 \mathrm{ka} \mathrm{BP}$, the ostracode fauna and its isotopic composition changed dramatically at the Lake Manitoba site, to dominance mainly by $C$. rawsoni, Limnocythere staplini and $L$. ceriotuberosa with enriched values of $\delta^{18} \mathrm{O},-5$ to -7.5 per mil. A similar fauna and isotopic composition were recovered from sediments deposited during the early part (about 9.5-9 ka BP) of the Nipigon phase of Lake Agassiz when its surface water inundated the Lake Manitoba site ( $<5 \mathrm{~m}$ deep) (Last $e t$ al., 1994). The site was then quite distant (Figs 8d, e, Lewis and Anderson, 1989) from the ice-marginal environment, owing to retreat of the Laurentide ice during the previous millenium. The enriched $\delta^{18} \mathrm{O}$ and the lack of $C$. subtriangulata in this fauna imply that the surface water in the southern sector of Lake Agassiz was dominated by precipitation runoff that contained $>100 \mathrm{mg} / \mathrm{l}$ TDS. This is the same type of water that flowed into the Superior and Huron basins during the Lake Mattawa highstands.

Thus, we postulate that fluctuations in the hydrology of the northern Huron basin between 9.6 and $7.5 \mathrm{ka}$ BP were largely driven by the relative proportions of inflows of meltwater and Lake Agassiz surface water. High volume outflows of Lake Agassiz surface water diluted and dominated the meltwater inflows, raised water levels in the Huron basin to the Mattawa highstands, and provided water characteristic of precipitation runoff which supported a TDS-tolerant ostracode fauna with a heavy $\delta^{18} \mathrm{O}$ shell composition. When the massive Agassiz inflows were not operating (shut off or impeded by ice advances, or diverted), water levels declined and the resulting lowstands in the Huron basin were dominated by a modest inflow of meltwater from the region north of the Nipigon basin or by backflooding from glacial Lake Ojibway. This water supported a TDS-intolerant ostracode fauna with extremely light $\delta^{18} \mathrm{O}$ shell composition. These influences would have been modulated by local processes of evaporation, precipitation and mixing.

\section{Demise of Lakes Agassiz and Ojibway}

If our scenario for the composition of inflows is true, the final lake-level decline and lightening of $\delta^{18} \mathrm{O}$ in the Huron basin beginning at about $8 \mathrm{ka}$ BP imply that Agassiz surface water discharge was diverted from the Great Lakes basins while meltwater inflow continued (Figs 10, 12). The isotope record shows that meltwater continued to dominate the Huron water over that of local precipitation and runoff to at least $7.5 \mathrm{ka}$ BP. Part of this continued meltwater signal may also be due to the residence time of water in the Huron basin after large diluting inflows from Lake Agassiz had declined. The implied 
late age for the demise of Lakes Agassiz and Ojibway is a few hundred years younger than the $8 \mathrm{ka} \mathrm{BP}$ inferred from the varve record, or the radiocarbon age of the marine transgression in the Hudson Bay lowlands which followed (Vincent, 1989). A drainage of Lake Agassiz slightly before Lake Ojibway is consistent with the cessation of major inflow to the Great Lakes by $8 \mathrm{ka} \mathrm{BP}$ and the evidence of a calving bay through the Laurentide Ice Sheet in western Hudson Bay, implied by iceberg scour features on the floor of the Bay (Fig. 1) (Josenhans and Zevenhuizen, 1990).

\section{Large Lakes and Climate Effects}

Widespread cooling around the Great Lakes basins, evidenced by vegetation change, has been correlated with inflows, thought to be dominated by meltwater, from glacial lakes Agassiz and Barlow-Ojibway into the largearea Main Algonquin and Mattawa lake phases at about 11-10.5 and 9.5-8 ka (Lewis and Anderson, 1989, 1992; Anderson and Lewis, 1992). The work of Colman et al. (1994a, b) in the Michigan basin and Moore et al. (1994), Rea et al. (1994a, b) and Smith et al. (submitted) in the Huron basin corroborate and clarify the alternating series of low and high lake levels which characterize the Mattawa-Stanley phase. However, the isotopic record from the northwestern Huron basin shows the Agassiz inflows to be more typical of precipitation runoff than of meltwater. Thus the mechanism for the enhanced lake cooling effect is more likely related to the co-occurrence of large inflow and large lake area than solely to the presence of cold meltwater. As Rea et al. (1994b) point out, "lakes need not be full of meltwater to freeze over in the winter and remain cold in the summer, with ice . . remaining much of the year; the situation for Hudson Bay today".

\section{SUMMARY}

The conditions for the formation of lakes in the Huron basin and its hydrological connections to downstream or upstream drainage basins are intimately linked to deglaciation and glacioisostatic crustal warping. The history of lakes and water supply since the last glacial maximum at $18-21 \mathrm{ka} \mathrm{BP}$ divides naturally into 3 periods, with some overlap, characterized by: (1) direct ice impoundment with mainly local meltwater and precipitation runoff (18-10 ka BP); (2) indirect glacial influence through overflow from external northern proglacial lake basins (about 11-7.5 ka BP); and (3) local precipitation runoff only, as at present. The history of the first two periods is the subject of this review and is summarized in Fig. 14. The evidence or likelihood for shorter term, smaller scale hydrological and climate-related fluctuations, as recognized in the third period (Larsen, 1985), is not reviewed here.

\section{Lakes and Drainage of Direct Ice Impoundment}

The first two sequences of Huron-basin lakes formed during ice recession to the Erie Interstadial position at about $15.5 \mathrm{ka} \mathrm{BP}$ and the Mackinaw Interstadial position at about $13.2 \mathrm{ka}$ BP (Figs 3, 4). Other than their existence, little is known about these lakes as ice refilled the basin after each recession and obliterated most evidence. It is inferred that drainage switched from Mississippi River to Hudson River tributaries during the first and second recessions; in the second, Huron-basin drainage to the Mississippi River passed westward for a time via the Michigan basin before switching eastward to the Hudson River tributaries. A third recession, following the Port Huron advance (about $13 \mathrm{ka} \mathrm{BP}$ ), introduced the final sequence of proglacial lakes in Huron basin, whose surface elevations, and inlet and outlet routes are known from better preserved evidence of former shorelines and ice margins (Figs 5, 14). This recession was punctuated by the Greatlakean advance in the Michigan basin and northwestern Lake Huron about $11.8 \mathrm{ka} \mathrm{BP}$, following the Two Creeks Interstade. Prior to this advance, drainage from the Huron basin went first to the Michigan basin and Mississippi River, then to the Atlantic Ocean via Hudson River tributaries. The drainage to the Hudson River progressed first through the Erie basin, then through the Ontario basin. After the Greatlakean advance, drainage continued via the Ontario basin and Hudson River, then about $11.6 \mathrm{ka} \mathrm{BP}$ to the Champlain Sea in the St. Lawrence Valley. Close to $11 \mathrm{ka} \mathrm{BP}$, the Huron-basin drainage switched to the Port Huron from the Fenelon Falls outlet, possibly due to differential uplift. Coincidently or shortly thereafter, major inflow began in the northwest from glacial Lake Agassiz. Closely following this inflow, at about $10.5-10 \mathrm{ka} \mathrm{BP}$, ice recession in the North Bay-Mattawa area ended the era of direct glacier impoundment as the Huron basin developed new outlets, first paralleling, then following the Mattawa River valley to the Ottawa River valley and the Champlain Sea (Figs 6a-d, 14).

\section{Lakes Influenced by Overflow from Northern Proglacial Lakes}

Overflow from glacial Lake Agassiz is inferred from shortly after 11 to $10 \mathrm{ka} \mathrm{BP}$. The period immediately after $11 \mathrm{ka} \mathrm{BP}$ shows more negative $\delta^{18} \mathrm{O}$ values (1-2 per mil) in ostracode shells from southern Lake Huron, southern Lake Michigan and Lake Erie, reflecting overflow from ice-marginal environments of glacial lake Agassiz into Main Lake Algonquin in the Great Lakes basin.

Up to 9 regional seismic reflectors truncate underlying sequences in the lacustrine sediments of northern Lake Huron and Georgian Bay, and correlate with zones of coarser grains and increased magnetic susceptibility in the offshore sediments. This record implies a sequence of lowstands and highstands from after 10.5 to $7.5 \mathrm{ka} \mathrm{BP}$, here termed the Mattawa-Stanley phase. Although the coarser-grained zones (reflectors) could be considered as evidence of turbulent flow during highstands caused, for example, by catastrophic inflows from Lake Agassiz, they are interpreted here as lowstands representing periods of low lake level when inflows were reduced or diverted. This interpretation is shown to be consistent with the independent stratigraphic record of shallow- 


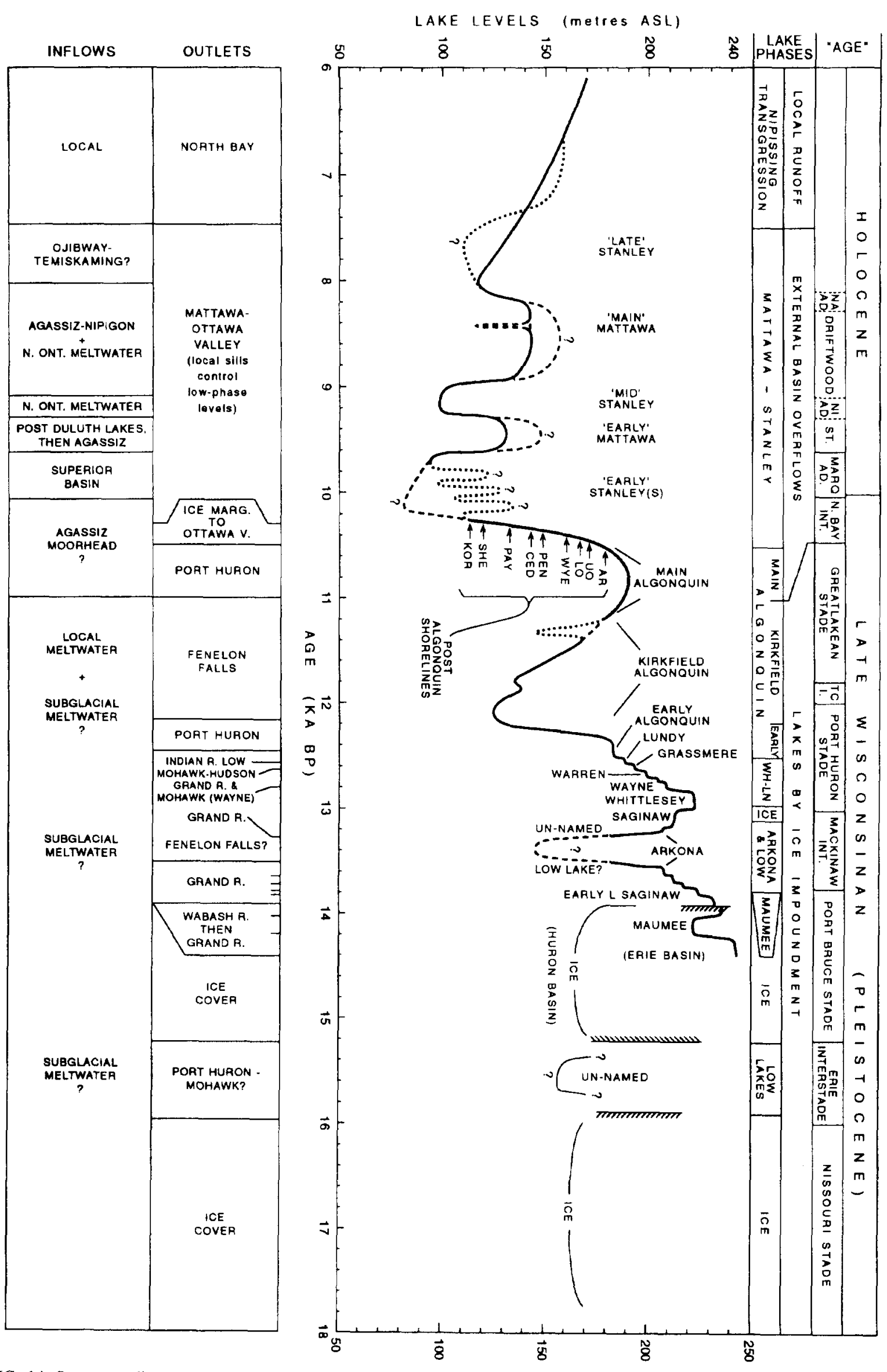

FIG. 14. Summary diagram of lake levels, outlets, inflows, phases and 'age' vs. radiocarbon age for the northern Huron basin. Abbreviations under 'age' and lake phases are: I, INT = Interstade; ST = Stade; $A D=$ advance; $N A=$ Nakina; NI = Nipigon; WH-LN = Whittlesey-Lundy. Line symbols for the lake level curve and the Post Algonquin shorelines are the same as in Fig. 10. Abbreviations under outlets and inflows are: $M A R G=\operatorname{margin} ; \mathrm{V}=$ valley; $\mathrm{R}=$ river; $\mathrm{N}$. ONT = northern Ontario. 
water sediments, which provide constraints on the ages and elevations of transgressions, regressions and stillstands of large lakes in the Huron basin. It is concluded that erosive turbulent conditions associated with catastrophic inflows were likely restricted to the North Channel north of Manitoulin Island (Fig. 2), a direct route between the upstream Superior basin and downstream Georgian Bay basin.

The reconstruction of lake level history from $11-6 \mathrm{ka}$ BP is based on the integrated evidence provided by the uplift history of outlets and radiocarbon-dated shallowwater sequences, which determine levels precisely, and the offshore seismic/sediment record, which best determines durations and changes in water-level trends. At least 4 lowstands and intervening highstands of uncertain cause are defined in the Huron basin between the end of the Main Algonquin phase at $10.5 \mathrm{ka} \mathrm{BP}$ and $9.6 \mathrm{ka} \mathrm{BP}$; the highstands could possibly be responsible for some of the well known Post Algonquin shorelines. The lowstands are thought to be phases of Early Lake Stanley. The following Early Lake Mattawa highstand is attributed to a combination of drainage from the Post Duluth glacial lakes in western Lake Superior and from Lake Agassiz into the Nipigon basin north of Lake Superior. The Huron water level descended tens of meters to the Mid Lake Stanley lowstand, which existed from about 9.3 to $9 \mathrm{ka} \mathrm{BP}$; this decline is attributed to blockage of the Agassiz inflow by an ice stream advance into the Nipigon basin. When Agassiz inflows were re-established, the Huron water level rose again, to the Main Lake Mattawa highstand. A short-lived recession is possibly associated with a brief reduction in inflows about 8.3-8.4 ka BP, just prior to the readvance of Laurentide ice to the Nakina Moraine north of the Nipigon basin. The Huron water level descended from the Main Lake Mattawa highstand about $8-8.1 \mathrm{ka}$ BP to the Late Lake Stanley lowstand from 7.8 to $7.5 \mathrm{ka} \mathrm{BP}$, presumedly as a result of the diversion of Lake Agassiz. This final lowstand is the low-level Lake Stanley stage originally identified by Hough (1962).

The ostracode and stable $\mathrm{O}$ isotope records for northern Lake Huron are highly variable and reflect the major changes in lake level. After $9.8 \mathrm{ka} \mathrm{BP}$, highstands were dominated by an ostracode fauna which was tolerant to total dissolved solids (TDS), and typically had a heavy $\delta^{18} \mathrm{O}$ shell composition, whereas lowstands were dominated by a TDS-intolerant fauna of $C$. subtriangulata with an extremely light $\delta^{18} \mathrm{O}$ shell composition. These changes are speculatively attributed to the episodic presence and absence, respectively, of large inflows from Lake Agassiz, in parallel with a more or less constant input of meltwater. The meltwater could possibly have originated directly from the ice-marginal environment north of the Nipigon basin, or by backflooding of glacial Lake Ojibway discharge from hydraulic constrictions in the Ottawa River valley. Our hypothesis is that, contrary to expectations, the Lake Agassiz discharge into the Great Lakes after 9.6 ka BP was characteristic of precipitation runoff, not meltwater. This unconventional sce- nario is probable because the ice-marginal environment of Lake Agassiz had retreated far to the north by this time; also, only surface water from the southern sector of Lake Agassiz, which was dominantly supplied by precipitation runoff, was likely draining into the Great Lakes. This scenario is consistent with the available ostracode faunal and $\delta^{18} \mathrm{O}$ isotopic records from Lake Agassiz sediments. Climatic cooling around the Great Lakes basin during highstands of the Mattawa-Stanley phase is most likely related to the co-occurrence of large-area lakes (highstands) and high inflows rather than the dominant presence of meltwater alone, as previously thought. The late age (7.5 ka BP) for meltwater presence in the Huron basin suggests that northern proglacial lakes existed later than $8 \mathrm{ka} \mathrm{BP}$. After the demise of the northern ice-marginal lakes, lakes throughout the Huron basin fell to their final lowstands (about $7.5 \mathrm{ka} \mathrm{BP}$ ). Subsequently, the Huron basin received only local precipitation runoff during the Nipissing transgression, and its lake level was controlled by the rising sill of the North Bay outlet.

\section{ACKNOWLEDGEMENTS}

We are pleased to acknowledge helpful discussions with L.H. Thorleifson, Geological Survey of Canada (GSC). We thank T.W. Anderson, S.M. Colman, P.F. Karrow, W.M. Last and J.T. Teller for their comments which helped us to greatly improve the manuscript. For the preparation of figures, we thank G. Grant of the Publications and Drafting Unit of the Atlantic Geoscience Centre, and J. Lord and R. Coulstring of Paragon Services. We acknowledge the Canadian Journal of Earth Sciences for permission to publish Figure 7. This paper was prepared with support from the Geological Survey of Canada and the Offshore Geotechnics Program of the Canada Panel on Energy Research and Development.

\section{REFERENCES}

Anderson, T.W. (1978). South Bay, Manitoulin Island, a preliminary report. In: Guidebook for the Michigan Basin Geological Society Field Trip on Manitoulin Island, September 29-October 1, 1978. Michigan Basin Geological Society.

Anderson, T.W. (1979). Stratigraphy, age, and environment of a Lake Algonquin embayment site at Kincardine, Ontario. Geological Survey of Canada, Paper 79-1B, 147-152.

Anderson, T.W. and Lewis, C.F.M. (1974). Chronology and paleoecology of an Holocene buried plant detritus bed in Lake Huron. 17th Conference on Great Lakes Research, Hamilton, Ontario. Abstracts, International Association for Great Lakes Research, p. 4.

Anderson, T.W. and Lewis, C.F.M. (1985). Postglacial waterlevel history of the Lake Ontario basin. In: Karrow, P.F. and Calkin, P.E. (eds), Quaternary Evolution of the Great Lakes, pp. 231-253. Geological Association of Canada, Special Paper 30.

Anderson, T.W. and Lewis, C.F.M. (1992). Climatic influences of deglacial drainage changes in southern Canada at 10 to 8 ka suggested by pollen evidence. Géographie Physique et Quaternaire, 46, 255-272.

Barnett, P.J. (1990). Tunnel valleys: Evidence of catastrophic release of subglacial meltwater, central-southern Ontario, Canada. In: Abstracts with Programs, Northeastern Section. Geological Society of America, Syracuse, New York, p. 3.

Barnett, P.J. (1992). Quaternary geology of Ontario. In: Thurston, 
P.C., Williams, H.R., Sutcliffe, R.H. and Scott, G.M. (eds), Geology of Ontario, pp. 1011-1088, Ontario Geological Survey, Special Volume 4, Part 2, Toronto, Ontario.

Broecker, W.S. and Farrand, W.R. (1963). Radiocarbon age of the Two Creeks forest bed, Wisconsin. Geological Society of America Bulletin, 74, 795-802.

Burgis, W. and Eschman, D.F. (1981). Late Wisconsinan history of northeastern Lower Michigan. 30th Conference, Midwest Friends of the Pleistocene, Guidebook, 110 pp. Ann Arbor, Michigan.

Calkin, P.E. and Feenstra, B.H. (1985). Evolution of the Erie Basin Great Lakes. In: Karrow, P.F. and Calkin, P.E. (eds), Quaternary Evolution of the Great Lakes, pp. 149-170. Geological Association of Canada, Special Paper 30.

Chapman, L.J. (1954). An outlet of Lake Algonquin at Fossmill, Ontario. Geological Association of Canada, Proceedings, 6, 61-68.

Chapman, L.J. (1975). The physiography of the Georgian BayOttawa Valley area of southern Ontario. Ontario Division of Mines, Geoscience Report 128, 33 pp.

Chapman, L.J. and Putnam, D.F. (1966). The Physiography of Southern Ontario. University of Toronto Press, Toronto, 386 $\mathrm{pp}$

Chapman, L.J. and Putnam, D.F. (1984). The Physiography of Southern Ontario. Ontario Geological Survey Special Volume 2. Ontario Ministry of Natural Resources, Toronto, Canada. 270 pp.

Clark, J.A., Pranger II, H.S., Walsh, J.K. and Primus, J.A. (1990). A numerical model of glacial isostasy in the Lake Michigan basin. Geological Society of America, Special Paper 251, 111-123.

Clark, J.A., Hendriks, M., Timmermans, T.J., Struck, C. and Hilverda, K.J. (1994). Glacial isostatic deformation of the Great Lakes region. Geology Society of America Bulletin, 106, 19-31.

Clayton, L. (1983). Chronology of Lake Agassiz drainage to Lake Superior. In: Teller, J.T. and Clayton, L. (eds), Glacial Lake Agassiz, pp. 291-307. Geological Association of Canada, Special Paper 26.

Coakley, J.P. and Karrow, P.F. (1994). Reconstruction of postIroquois shoreline evolution in western Lake Ontario. Canadian Journal of Earth Sciences, 31, 1618-1629.

Colman, S.M., Forester, R.M., Reynolds, R.L., Sweetkind, D.S., King, J.W., Gangemi, P., Jones, G.A., Keigwin, L.D. and Foster, D.S. (1994a). Lake-level history of Lake Michigan for the past 12,000 years: The record from deep lacustrine sediments. Journal of Great Lakes Research, 20, 73-92.

Coleman, S.M., Jones, G.A., Forester, R.M. and Foster, D.S. (1990). Holocene paleoclimatic evidence and sedimentation rates from a core in southwestern Lake Michigan. Journal of Paleolimnology, 4, 269-284.

Colman, S.M., Keigwin, L.D. and Forester, R.M. (1994b). Two episodes of meltwater influx from glacial Lake Agassiz into the Lake Michigan basin and their climatic contrasts. Geology, 22, 547-550.

Cowan, W.R. (1978). Radiocarbon dating of Nipissing Great Lakes events near Sault Ste. Marie, Ontario. Canadian Journal of Earth Sciences, 15, 2026-2030.

Cowan, W.R. (1985). Deglacial shorelines at Sault Ste. Marie, Ontario. In: Karrow, P.F. and Calkin, P.E. (eds), Quaternary Evolution of the Great Lakes, pp. 33-37. Geological Association of Canada, Special Paper 30.

Crane, H.R. and Griffin, J.B. (1961). University of Michigan Radiocarbon Dates VI. Radiocarbon, 3, 105-125.

Crane, H.R. and Griffin, J.B. (1968). University of Michigan Radiocarbon Dates XII. Radiocarbon, 10, 61-114.

Crane, H.R. and Griffin, J.B. (1970). University of Michigan Radiocarbon Dates XIII. Radiocarbon, 12, 161-180.

Crane, H.R. and Griffin, J.B. (1972). University of Michigan Radiocarbon Dates XV. Radiocarbon, 14, 195-222.

Deane, R.E. (1950). Pleistocene geology of the Lake Simcoe district, Ontario. Geological Survey of Canada, Memoir 256, $108 \mathrm{pp}$.

Dell, C.I. (1972). The origin and characteristics of Lake Superior sediments. 15th Conference on Great Lakes Research, Ann Arbor, Michigan. Proceedings, International Association for Great Lakes Research, pp. 361-370.

Dell, C.I. (1974). The stratigraphy of northern Lake Superior late-glacial and postglacial sediments. 17th Conference on Great Lakes Research, Hamilton, Ontario. Proceedings. International Association for Great Lakes Research, pp. $179-192$.

Dell, C.I. (1975). Relationships of till to bed rock in the Lake Superior region. Geology, 3, 563-564.

Dettman, D.L., Smith, A.M., Rea, D.K., Lohmann, K.C. and Moore, T.C., Jr (in press). Glacial melt-water in Lake Huron during early post-glacial times as inferred from single value analysis of oxygen isotopes in ostracodes.

Dredge, L.A. and Cowan, W.R. (1989). Quaternary geology of the southwestern Canadian Shield. In: Fulton, R.J., Heginbottom, J.A. and Funder, S. (eds), Quaternary Geology of Canada and Greenland, pp. 214-249. Geological Survey of Canada, Geology of Canada 1 (also Geological Society of America, The Geology of North America, K-1).

Dreimanis, A. (1958). Beginning of the Nipissing phase of Lake Huron. Journal of Geology, 66, 591-594.

Dreimanis, A. (1969). Late-Pleistocene lakes in the Ontario and Erie basins. 12th Conference on Great Lakes Research, Ann Arbor, Michigan. Proceedings, International Association for Great Lakes Research, pp. 170-180.

Dyke, A.S. and Prest, V.K. (1987). Late Wisconsinan and Holocene history of the Laurentide ice sheet. Géographie Physique et Quaternaire, 41, 237-263.

Eschman, D.F. and Karrow, P.F. (1985). Huron basin Glacial Lakes: A review. In: Karrow, P.F. and Calkin, P.E. (eds) Quaternary Evolution of the Great Lakes, pp. 79-93. Geological Association of Canada, Special Paper 30.

Evenson, E.B. and Dreimanis, A. (1976). Late Glacial (14,000-10,000 years B.P.) history of the Great Lakes region and its possible correlations. In: Easterbrook, D.J. and Sibrava, V. (eds), Quaternary Glaciations in the Northern Hemisphere, Project 73-1-24, Report no. 3 on the session in Bellingham Washington, U.S.A., Sept. 1975, UNESCO International Geological Correlation Program, pp. $217-$ 239.

Farrand, W.R. (1960). Former shorelines in western and northern Lake Superior basin. Ph.D. thesis, University of Michigan, Ann Arbor, Michigan, 266 pp.

Farrand, W.R. (1969a). Late-glacial and postglacial sedimentation in the deep basins of Lake Superior, USA. Mitteilungen Internationale Vereingung für Theoretische und Angewandte Limnologie, 17, 34-42.

Farrand, W.R. (1969b). The Quaternary history of Lake Superior. 12th Conference on Great Lakes Research, Ann Arbor, Michigan. Proceedings, International Association for Great Lakes Research, pp. 181-197.

Farrand, W.R. and Drexler, C.W. (1985). Late Wisconsinan and Holocene history of the Lake Superior basin. In: Karrow, P.F. and Calkin, P.E. (eds), Quaternary Evolution of the Great Lakes, pp. 17-32. Geological Association of Canada, Special Paper 30.

Farrand, W.R. and Eschman, D.F. (1974). Glaciation of the Southern Penninsula of Michigan: A review. Michigan Academician, 7, 31-56.

Finamore, P.F. (1985). Glacial Lake Algonquin and the Fenelon Falls outlet. In: Karrow, P.F. and Calkin, P.E. (eds), Quaternary Evolution of the Great Lakes, pp. 125-132. Geological Association of Canada, Special Paper 30

Ford, M.J, and Geddes, R.S. (1986). Quaternary geology of the Algonquin Park area. Ontario Geological Survey, Open File Report 5600, 87 pp.

Forester, R.M., Colman, S.M., Reynolds, R.L. and Keigwin, 
L.D. (1994). Lake Michigan's Late Quaternary limnological and climate history from ostracode, oxygen isotope, and magnetic susceptibility. Journal of Great Lakes Research, 20, 93-107.

Fritz, P., Anderson, T.W. and Lewis, C.F.M. (1975). LateQuaternary climatic trends and history of Lake Erie from stable isotope studies. Science, 190, 267-269.

Fullerton, D.S. (1980). Preliminary correlation of post-Erie interstadial events (16,000-10,000 radiocarbon years before present), central and eastern Great Lakes region, and Hudson, Champlain, and St. Lawrence Lowlands, United States and Canada. United States Geological Survey, Professional Paper 1089, 52 pp.

Futyma, R.P. (1981). The northern limits of Lake Algonquin in Upper Michigan. Quaternary Research, 15, 291-310.

Futyma, R.P. and Miller, N.G. (1986). Stratigraphy and genesis of the Lake Sixteen peatland, northern Michigan. Canadian Journal of Botany, 64, 3008-3019.

Goldthwait, J.W. (1907). Abandoned shorelines of eastern Wisconsin. Wisconsin Geological and Natural History Survey Bulletin, 17, $134 \mathrm{pp}$.

Goldthwait, J.W. (1908). A reconstruction of water planes of the extinct glacial lakes in the Lake Michigan basin. Journal of Geology, 16, 459-476.

Goldthwait, J.W. (1910). An instrumental survey of the shorelines of extinct lakes in southwestern Ontario. Geological Survey of Canada Memoir, 10, $57 \mathrm{pp}$.

Graham, E.J. and Rea, D.K. (1980). Grain size and mineralogy of sediment cores from western Lake Huron. Journal of Great Lakes Research, 6, 129-140.

Hansel, A.K., Mickelson, D.M., Schneider, A.F. and Larsen, C.E. (1985). Late Wisconsinan and Holocene history of the Lake Michigan basin. In: Karrow, P.F. and Calkin, P.E. (eds), Quaternary Evolution of the Great Lakes, pp. 40-53. Geological Association of Canada, Special Paper 30.

Harrison, J.E. (1970). Deglaciation and proglacial drainage: North Bay-Mattawa region, Ontario. 13th Conference on Great Lakes Research, Buffalo, New York. Proceedings, International Association of Great Lakes Research, pp. 756-767.

Harrison, J.E. (1972). Quaternary geology of the North Bay-Mattawa region. Geological Survey of Canada, Paper $71-26,37 \mathrm{pp}$.

Hough, J.L. (1955). Lake Chippewa, a low stage of Lake Michigan indicated by bottom sediments. Geological Society of America Bulletin, 66, 957-968.

Hough, J.L. (1958). Geology of the Great Lakes. University of Illinois Press, Urbana, Illinois, $313 \mathrm{pp}$.

Hough, J.L. (1962). Lake Stanley, a low stage of Lake Huron indicated by bottom sediments. Geological Society of America Bulletin, 73, 613-620.

Hough, J.L. (1963). The prehistoric Great Lakes of North America. American Scientist, 51, 84-109.

Hough, J.L. (1966). Correlation of glacial stages in the Huron-Erie and Michigan Basins. Journal of Geology, 74, 62-77.

Hough, J.L. (1968). Great Lakes (North America). In: Fairbridge, R.W. (ed.), The Encyclopedia of Geomorphology, Encyclopedia of Earth Sciences, Volume III, pp. 499-506. Reinhold, New York.

Hughes, T. (1987). Ice dynamics and deglaciation models when ice sheets collapsed. In: Ruddiman, W.F. and Wright, H.E., $\mathrm{Jr}$ (eds), North America and Adjacent Oceans During the Last Deglaciation, pp. 183-220. Decade of North American Geology, K-3. Geological Society of America, Boulder, Colorado.

Johnston, W.A. (1916). The Trent valley outlet of Lake Algonquin and the deformation of the Algonquin waterplane in Lake Simcoe district, Ontario. Geological Survey of Canada, Museum Bulletin, 23, 27 pp.

Josenhans, H.W. and Zevenhuizen, J. (1990). Dynamics of the
Laurentide Ice Sheet in Hudson Bay, Canada. Marine Geology, 92, 1-26.

Kamb, B., Raymond, C.F., Harrison, W.D., Englehardt, H., Echelmeyer, K.A., Humphrey, N., Arugman, M.M. and Pfetter, T. (1985). Glacial surge Mechanism: 1982-1983 surge of Variegated Glacier, Alaska. Science, 227, 469-479.

Karrow, P.F. (1980). The Nipissing transgression around southern Lake Huron. Canadian Journal of Earth Sciences, 17, 1271-1279.

Karrow, P.F. (1986). Valley terraces and Huron basin water levels, southwestern Ontario. Geological Society of America Bulletin, 97, 1089-1097.

Karrow, P.F. (1987). Glacial and glaciolacustrine events in northwestern Lake Huron, Michigan and Ontario. Geological Society of America Bulletin, 98, 113-120.

Karrow, P.F. (1989). Quaternary geology of the Great Lakes subregion. In: Fulton, R.J., Heginbottom, J.A. and Funder, S. (eds), Quaternary Geology of Canada and Greenland, pp. 326-350. Geology of Canada 1, Geological Survey of Canada (also Geological Society of America, The Geology of North America, K-1).

Karrow, P.F. and Geddes, R.S. (1987). Drift Carbonate on the Canadian Shield. Canadian Journal of Earth Sciences, 24, 365-369.

Karrow, P.F., Anderson, T.W., Clarke, A.H., Delorme, L.D. and Sreenivasa, M.R. (1975). Stratigraphy, paleontology and age of Lake Algonquin sediments in southwestern Ontario, Canada. Quaternary Research, 5, 49-87.

Kaszycki, C.A. (1985). History of Glacial Lake Algonquin in the Haliburton region, south central Ontario. In: Karrow, P.F. and Calkin, P.E. (eds), Quaternary Evolution of the Great Lakes, pp. 110-123. Geological Association of Canada, Special Paper 30.

Kor, P.S.G., Shaw, J. and Sharpe, D.R. (1991). Erosion of bedrock by subglacial meltwater, Georgian Bay, Ontario: A regional view. Canadian Journal of Earth Sciences, $\mathbf{2 8}$, 623-642.

Larson, D.W. and Kelly, P.E. (1994). Holocene remnants of Niagara escarpment Thuja Occidentalis forests: Ecological, hydrological and geological implications. Geological Association of Canada, Program with Abstracts, 19, A61.

Larsen, C.E. (1985). Lake level, uplift, and outlet incision, the Nipissing and Algoma Great Lakes. In: Karrow, P.F. and Calkin, P.E. (eds), Quaternary Evolution of the Great Lakes, pp. 63-77. Geological Association of Canada, Special Paper 30.

Larsen, C.E. (1987). Geological history of Glacial Lake Algonquin and the Upper Great Lakes. United States Geological Survey Bulletin, 1801, 36 pp.

Larsen, C.E. (1994). Beach monitors of isostatic uplift in the upper Great Lakes. Journal of Great Lakes Research, 20, $108-134$.

Larson, G.J., Lowell, T.V. and Ostrom, N.E. (1994). Evidence for the Two Creeks interstade in the Lake Huron basin. Canadian Journal of Earth Sciences, 31, 793-797.

Last, W.M., Teller, J.T. and Forester, R.M. (1994). Paleohydrology and paleochemistry of Lake Manitoba, Canada: The isotope and ostracode records. Journal of Paleolimnology, 12, 269-282.

Lee, T.E. (1957). The antiquity of the Sheguiandah Site. The Canadian Field-Naturalist, 71, 117-147.

Leverett, F. and Taylor, F.B. (1915). The Pleistocene of Indiana and Michigan and the history of the Great Lakes. United States Geological Survey, Monograph, 53, $529 \mathrm{pp}$.

Lewis, C.F.M. (1969). Late Quaternary history of lake levels in the Huron and Erie basins. 12th Conference on Great Lakes Research, Ann Arbor, Michigan. Proceedings, International Association of Great Lakes Research, pp. 250-270.

Lewis, C.F.M. (1970). Recent uplift of Manitoulin Island, Ontario. Canadian Journal of Earth Sciences, 7, 665-675. 
Lewis, C.F.M. and Anderson, T.W. (1985). Postglacial lake levels in the Huron basin: Comparative uplift histories of basins and sills in a rebounding glacial marginal depression (Abst.). In: Karrow, P.F. and Calkin, P.E. (eds), Quaternary Evolution of the Great Lakes, pp. 147-148. Geological Association of Canada, Special Paper 30.

Lewis, C.F.M. and Anderson, T.W. (1989). Oscillations of levels and cool phases of the Laurentian Great Lakes caused by inflows from glacial Lakes Agassiz and Barlow-Ojibway. Journal of Paleolimnology, 2, 99-146.

Lewis, C.F.M. and Anderson, T.W. (1992). Stable isotope $(\mathrm{O}$ and $\mathrm{C}$ ) and pollen trends in Lake Erie, evidence for a locally-induced climatic reversal of Younger Dryas age in the Great Lakes basin. Climate Dynamics, 6, 241-250.

Lineback, J.A., Dell, C.I. and Gross, D.L. (1979). Glacial and postglacial sediments in Lakes Superior and Michigan. Geological Society of America Bulletin, 90, 781-791.

Lowdon, J.A., Fyles, J.G. and Blake, W., Jr (1967). Geological Survey of Canada Radiocarbon Dates VI. Geological Survey of Canada, Paper 67-2, Part B, 42 pp.

Lowdon, J.A., Robertson, I.M. and Blake, W., Jr (1971). Geological Survey of Canada Radiocarbon Dates XI. Geological Survey of Canada, Paper 71-7, 255-324.

McAtee, C.L. (1977). Palynology of late-glacial and postglacial sediments in Georgian Bay, Ontario, Canada, as related to Great Lakes history. M.Sc. thesis, Brock University, St. Catharines, Ontario, $153 \mathrm{pp}$.

Miller, B.B., Karrow, P.F. and Mackie, G.L. (1985). Late Quaternary molluscan faunal changes in the Huron basin. In: Karrow, P.F. and Calkin, P.E. (eds), Quaternary Evolution of the Great Lakes, pp. 95-107. Geological Association of Canada, Special Paper 30.

Monaghan, G.W., Lovis, W.A. and Fay, L. (1986). The Lake Nipissing transgression in the Saginaw Bay region, Michigan. Canadian Journal of Earth Sciences, 23. $1851-1854$

Moore, T.C., Jr, Rea, D.K., Mayer, L.A., Lewis, C.F.M. and Dobson, D.M. (1994). Seismic stratigraphy of Lake Huron-Georgian Bay and post-glacial lake level history. Canadian Journal of Earth Sciences, 31, 1606-1617.

Morner, N.-A. and Dreimanis, A. (1973). The Erie Interstadial. Geological Society of America Memoir, 136, $334 \mathrm{pp}$.

Mothersill, J.S. (1988). Paleomagnetic dating of late glacial and postglacial sediments in Lake Superior. Canadian Journal of Earth Sciences, 25, 1791-1799.

Prest, V.K. (1970). Quaternary geology of Canada. In: Douglas, R.J.E. (ed.), Geology and Economic Minerals of Canada, pp. 675-764. Geological Survey of Canada, Economic Geology Report 1.

Rea, D.K. and Colman, S.M. (in press). Radiocarbon ages of pre-bomb clams and the hard-water effect in Lakes Michigan and Huron. Journal of Paleolimnology.

Rea, D.K., Moore, T.C., Jr, Anderson, T.W., Lewis, C.F.M., Dobson, D.M., Dettman, D.L., Smith, A.J. and Mayer, L.A. (1994a). Great Lakes paleohydrology: Complex interplay of glacial lake levels, and sill depths. Geology, 22, $1059-1602$.

Rea, D.K., Moore, T.C. Jr, Lewis, C.F.M., Mayer, L.A., Dettman, D.L., Smith, A.M. and Dobson, D.M. (1994b). Stratigraphy and paleolimnologic record of lower Holocene sediments in northern Lake Huron and Georgian Bay. Canadian Journal of Earth Sciences, 31, 1586-1605.

Rea, D.K., Owen, R.M. and Meyers, P.A. (1981). Sedimentary processes in the Great Lakes. Reviews of Geophysics and Space Physics, 19, 635-648.

Rodrigues, C.G. and Vilks, G. (1994). The impact of glacial lake runoff on Champlain and Goldthwait Seas: Implications for the relationship between Glacial Lake Agassiz runoff and the Younger Dryas. Quaternary Science Reviews, 13, 923-944.

Saarnisto, M. (1974). The deglaciation history of the Lake
Superior region and its climatic implications. Quaternary Research, 4, 316-339.

Saarnisto, M. (1975). Stratigraphical studies on the shoreline displacement of Lake Superior. Canadian Journal of Earth Sciences, 12, 300-319.

Sharpe, D.R. and Cowan, W.R. (1990). Moraine formation in northwestern Ontario: Product of subglacial fluvial and glaciolacustrine sedimentation. Canadian Journal of Earth Sciences, 11, 1478-1486.

Sly, P.G. (1978). Sedimentary processes in lakes. In: Lerman, A. (ed.), Lakes Chemistry, Geology, Physics, pp. 65-89. Springer, New York.

Sly, P.G. and Lewis, C.F.M. (1972). The Great Lakes of Canada - Quaternary geology and limnology. 24th International Geological Congress, Guidebook for Field Excursion A43, $92 \mathrm{pp}$. Montreal, Quebec.

Sly, P.G. and Sandilands, R.G. (1988). Geology of environmental significance of sediment distribution in an area of the submerged Niagara escarpment, Georgian Bay. In: Munawar, M. (ed.), Limnology and Fisheries of Georgian Bay and the North Channel Ecosystem. Hydrobiologia, 163. 47-76.

Sly, P.G. and Thomas, R.L. (1974). Review of geological research as it relates to an understanding of Great Lakes limnology. Journal of the Fisheries Research Board of Canada. 31, 795-825.

Smith, A.J., Dettman, D., Rea, D.K., Moore, T.C., Jr, Lewis, C.F.M., Mayer, L.A. and Dobson, D. (submitted). The early Holocene history of glacial melt water events in northern Lake Huron from the ostracode record. Journal of Paleolimnology.

Spencer, J.W. (1891). Deformation of the Algonquin Beach, and birth of Lake Huron. American Journal of Science, 41. 12-21.

Stanley, G.M. (1934). Pleistocene potholes in the Cloche Mountains of Ontario. Papers of the Michigan Academy of Science, Arts and Letters, 19, 401-412.

Stanley, G.M. (1936). Lower Algonquin beaches of Penetanguishene Peninsula. Geological Society of America Bulletin, 47, 1933-1959.

Stanley, G.M. (1937). Lower Algonquin beaches of Cape Rich. Georgian Bay. Geological Society of America Bulletin, $\mathbf{4 8}$. $1665-1686$.

Stanley, G.M. (1938). The submerged valley through Mackinac Straits. Journal of Geology, 46, 966-974.

Taylor, F.B. (1897). The Nipissing-Mattawa River, the outlet of the Nipissing Great Lakes. The American Geologist, 20 , 65-66.

Teller, J.T. (1985). Glacial Lake Agassiz and its influence on the Great Lakes. In: Karrow, P.F. and Calkin, P.E. (eds), Quaternary Evolution of the Great Lakes, pp. 1-16. Geological Association of Canada, Special Paper 30.

Teller, J.T. (1987). Proglacial lakes and the southern margin of the Laurentide Ice Sheet. In: Ruddiman, W.F. and Wright, H.E., Jr (eds), North America and Adjacent Oceans During the Last Deglaciation, pp. 39-69. Decade of North American Geology K-3. Geological Society of America, Boulder, Colorado.

Teller, J.T. (1990). Volume and routing of Late-Glacial runoff from the Southern Laurentide Ice Sheet. Quaternary Research. 34, 12-23.

Teller, J.T. and Thorleifson, L.H. (1983). The Lake Agassiz-Lake Superior connection. In: Teller, J.T. and Clayton, L. (eds), Glacial Lake Agassiz, pp. 261-290. Geological Association of Canada, Special Paper 26.

Teller, J.T. and Thorleifson, L.H. (1987). Catastrophic flooding into the Great Lakes from Lake Agassiz. In: Mayer, L. and Nash, D. (eds), Catastrophic Flooding, pp. 121-138. Allen and Unwin, London.

Teller, J.T. and Mahnic, P. (1988). History of sedimentation in the northwestern Lake Superior basin and its relation to 
Lake Agassiz overflow. Canadian Journal of Earth Sciences, 25, 1660-1673.

Terasmae, J. (1979). Radiocarbon dating and palynology of Glacial Lake Nipissing deposits at Wasaga Beach, Ontario. Journal of Great Lakes Research, 5, 292-330.

Terasmae, J. and Hughes, O.L. (1960). Glacial retreat in the North Bay area, Ontario. Science, 131, 1444-1446.

Thomas, R.L. (1988). Distribution and composition of the surficial sediments of Georgian Bay and North Channel. In: Munawar, M. (ed.), Limnology and Fisheries of Georgian Bay and the North Channel Ecosystem. Hydrobiologia, 163, $35-45$.

Thomas, R.L., Kemp, A.L.W. and Lewis, C.F.M. (1973). The surficial sediments of Lake Huron. Canadian Journal of Earth Sciences, 10, 226-271.

Thorleifson, L.H. and Kristjansson, F.J. (1993). Quaternary geology and drift prospecting, Beardmore-Geraldton area, Ontario. Geological Survey of Canada Memoir, 435, $146 \mathrm{pp}$.

Tinkler, K.J., Pengelly, J.W., Parkins, W.G. and Terasmae, J. (1992). Evidence for high water levels in the Erie basin during the Younger Dryas chronozone. Journal of Paleolimnology, 7, 214-234.

Tovell, W.M., McAndrews, J.H., Lewis, C.F.M. and Anderson, T.W. (1972). Geological reconnaissance of Georgian Bay A preliminary statement. 15th Conference on Great Lakes Research, Ann Arbor, Michigan. Abstracts, International Association for Great Lakes Research, p. 15.

Veillette, J. (1988). Déglaciation et évolution des lacs proglaciaires Post-Algonquin et Barlow au Témiscamingue, Québec et Ontario. Géographie Physique et Quaternaire, 42, 7-31.

Vincent, J.-S. (1989). Quaternary geology of the southeastern Canadian Shield. In: Fulton, R.J., Heginbottom, J.A. and Funder, S. (eds), Quaternary Geology of Canada and Greenland, pp. 249-275. Geology of Canada 1, Geological Survey of Canada (also Geological Society of America, The Geology of North America, K-1).

Vincent, J.-S. and Hardy, L. (1979). The evolution of Glacial Lakes Barlow and Ojibway, Quebec and Ontario. Geological Survey of Canada Bulletin, 316, 18 pp.

Walcott, R.I. (1972). Late Quaternary vertical movements in eastern North America: Quantitative evidence of glacio-isostatic rebound. Reviews of Geophysics and Space Physics. 10, 849-884.

Warner, B.G., Hebda, R.J. and Hann, B.J. (1984). Postglacial paleoecological history of a cedar swamp, Manitoulin Island, Ontario, Canada. Palaeogeography, Palaeoclimatology, Palaeoecology, 45, 301-345.

Woodend, S.L. (1983). Glacial and post-glacial history of Lake Huron as defined by lithological and palynological analysis of a core in southern Lake Huron, with special regard to a low-lake level phase. B.Sc. thesis, Carleton University, Ottawa, Ontario, $74 \mathrm{pp}$.

Zilans, A. (1985). Quaternary geology of the Mackinac basin, Lake Huron. M.Sc. thesis, University of Waterloo, Waterloo, Ontario, $275 \mathrm{pp}$.
Zilans, A. (1991). Quaternary Geology of the Mackinac Basin, Lake Huron. Ontario Geological Survey, Open File Report, 5799, $108 \mathrm{pp}$.

\section{APPENDIX}

\section{Expressions for Computing Former Site Elevations}

Empirical modeling of glacioisostatic rebound in the Great Lakes basins is commonly based on the assumption that uplift can be described as an exponential function of time (for uplift at a site) or of distance (for uplift between sites) (Larsen, 1987, 1994; Lewis and Anderson, 1989; Coakley and Karrow, 1994). The expressions for computing the elevation of a site undergoing uplift in the Huron-Georgian Bay basin at age $t \mathrm{ka} \mathrm{BP}$ follow the derivations in Lewis and Anderson, 1985, p. 145, 1989, p. 128:

$$
E_{t}=E_{\mathrm{p}}-U_{\mathrm{A}}^{*} \exp ^{k\left(T_{\mathrm{A}}-t\right)}
$$

where $E_{t}=$ desired site elevation at age $t$ ka BP;

$E_{\mathrm{p}}=$ present site elevation;

$U_{\mathrm{A}}=$ uplift remaining from age $T_{\mathrm{A}} \mathrm{ka} \mathrm{BP}=$ uplift of the Algonquin shoreline $=$ present Algonquin shore elevation at the site - Algonquin shore elevation near Port Huron (184 m a.s.l.);

$T_{\mathrm{A}}=$ age of Algonquin shore; here taken as $10.7 \mathrm{ka} \mathrm{BP}$ north of isobase through Fenelon Falls outlet area, and 10.5 ka BP south of the same isobase;

$k=\quad$ relaxation coefficient $=0.38 \pm 0.01$. This is the mean of $k$ values computed from the change in Algonquin and Nipissing waterplane elevations between pairs of reference sites 1 and 2, specifically North Bay and Sault Ste. Marie, Whitefish north of Little Current, Lucas Channel between Tobermory and South Bay, and Fenelon Falls. The expression for computing $k$ follows Anderson and Lewis, 1985, p. 253:

$$
k=1 /\left(T_{\mathrm{A}}-T_{\mathrm{N}}\right) * \log _{\mathrm{e}}\left(U_{\mathrm{N} 1}-U_{\mathrm{N} 2}\right) /\left(U_{\mathrm{A} 1}-U_{\mathrm{A} 2}\right)
$$

where

$T_{\mathrm{A}}=\quad$ age of Algonquin shore as above;

$T_{\mathrm{N}}=\quad$ age of Nipissing shore, here taken as $5 \mathrm{ka} \mathrm{BP}$;

$U_{\mathrm{N} 1} U_{\mathrm{N} 2}=$ post Nipissing uplift at sites 1 and 2 , respectively;

$U_{\mathrm{A} 1} U_{\mathrm{A} 2}=$ post Algonquin uplift at sites 1 and 2 , respectively.

Following Eqn. (1) above, the original elevation of a site at age $t \mathrm{ka}$ BP equals the present elevation of the site or $E_{\mathrm{p}}$ less the amount of uplift remaining at age $t$. This last quantity is the amount of uplift remaining from age $T_{\mathrm{A}}$ ka BP, or $U_{\mathrm{A}}$, exponentially decayed over the period $T_{\mathrm{A}}-t \mathrm{ka}$. 